\title{
Causes of G20 Compliance: Institutionalization, Hegemony, Reciprocity or Clubs $^{1}$
}

\author{
J. Kirton, A. Nikolaeva
}

John Kirton - PhD, Professor, Director of G20 Research Group, University of Toronto; 1 Devonshire Place, Room 209 N, Toronto, M5S 3K7 Ontario, Canada; E-mail: john.kirton@utoronto.ca

Alisa Nikolaeva - M.A., Research Associate, G20 Research Group; University of Toronto; 1 Devonshire Place, Room 209 N, Toronto, M5S 3K7 Ontario, Canada; E-mail: alisanik@bu.edu

\begin{abstract}
In recent years, multilateralism has faced significant challenges. The rise of populist sentiment in western countries, trade wars and now slowing economic growth have undermined trust in multilateral institutions including those of a plurilateral summit form. The Group of Twenty (G20) often faces criticism for its ineffective problem-solving and members' poor compliance with their summit commitments. Yet evidence from the G20 Research Group shows that G20 members do comply solidly with the commitments they make at one summit before the next one takes place. Some summits and subjects have secured higher compliance than others. Understanding what causes compliance and how it can be improved is essential for improving $G 20$ effectiveness, credibility and even its future. This study offers an exploratory quantitative analysis of performance at $G 20$ summits. It relies on established conceptual frameworks and presents a descriptive inferential argument. Compliance coincides with, and thus might be improved by, making more summit commitments, holding ministerial meetings and using specific catalysts in the commitments, given the prevailing reciprocity in compliance among members rather than a single dominant actor such as the U.S. or China setting the pace.
\end{abstract}

Key words: G20; global governance; compliance; accountability

For citation: Kirton J., Nikolaeva A. (2019) Causes of G20 Compliance: Institutionalization, Hegemony, Reciprocity or Clubs. International Organisations Research Journal, vol. 14, no 2, pp. 80-108 (in Russian and English). DOI: 10.17323/1996-7845-2019-02-04.

\section{Introduction}

The Group of Twenty (G20) is often seen as ineffective in solving global policy challenges and is criticized for its members' poor compliance with their summit commitments. However, some summits have been more successful than others and commitments on some subjects secured higher compliance than others. Understanding the causes of this variation in compliance with commitments is essential to improving the effectiveness of the G20 as an informal global summit institution. There is now an extensive literature on compliance with the commitments made at the older, smaller Group of Seven (G7) summits [Kirton, Larionova, 2018a] but very little is known about G20 summits [Cicci, 2018; Hallink, 2018; Kirton, Larionova, 2018a; Kokotsis, 2018; Kulik, 2018; Marchyshyn, 2018; Motala, 2018; Rudich, 2018; Tops, 2018; Wang, 2018; Warren, 2018a; 2018b; Williams, 2018].

${ }^{1}$ The editorial board received the article in February 2019. 
This article explores the causes of compliance with commitments made at the 12 G20 summits from Washington in 2008 to Hamburg in 2017. The causes of compliance are complex and can be found at both the international level and domestically within member governments. Individual countries' compliance may well be caused by the members' individual priorities or interests, even if these are at times elusive and rapidly changing. However, as the high profile G20 summits have a broad agenda and as their commitments are based on the consensus of all members, it can be assumed that each country sees these commitments as part of their priorities for their international and domestic policy, at least to an acceptable degree. Indeed, when a country does not, it explicitly does not accept the commitment, as seen most recently with the U.S. withdrawal from the climate change commitments resulting in the production by the G20 of a subset of commitments that bound only the U.S. or the other 19 members. It is certainly possible that a country's priorities change over the course of the summit year after its leader agreed to them. But while changing international and domestic political environments pose a challenge to understanding the causes of compliance, an analytical foundation can be laid using this collective acceptance assumption.

This study, based on the consensus collective acceptance assumption about members' priorities, focuses on the compliance-enhancing accountability measures that are under the direct control of leaders, are relatively inexpensive to use and have been used before [Kirton, Larionova, 2018a, 2018b]. The leading accountability measures are: the catalysts contained in the text of the commitment; companion commitments made at the same summit; iteration by leaders from their previous summits; ministerial meeting reinforcement; official body support; civil society participation; autonomous assessment; surrounding summit support; reinforcement by multilateral organizations; and enforcement sanctions and support [Kirton, Larionova, 2018a, 2018b]. This study explores three of the most promising accountability measures: companion commitments, ministerial reinforcement and catalysts. It analyzes the relationship between the number of companion commitments, ministerial meetings and specific catalysts in each summit period and the compliance with their commitments. It also considers the effect of the dynamics of hegemony, reciprocity and component clubs on G20 compliance. The argument is based on an exploratory quantitative analysis which does not isolate the causal effect of each accountability measure. This study thus provides a theoretical framework that makes it possible to draw descriptive logical inferences.

\section{Theory}

Countries' compliance with their international commitments has long been a central concern of scholars and practitioners of international relations and foreign policy. Realists claim that international institutions and regimes are shaped and reinforced by the dominance of a hegemon. They suggest that the weak comply and the strong do not. Liberal institutionalists claim that international institutions create a platform for cooperation thus eliminating conflicts and misunderstanding between members [Keohane, 1984; 2006; 2011]. G20 summits help leaders to overcome their differences and to come to a consensus, thus producing reciprocal compliance. Constructivists emphasize how institutions provide the channels for communication that allow states to reconstruct their interests in ways that conform to the consensus of the club [Wendt, 2012].

These theoretical assumptions form the foundation for the models that aim to explain $\mathrm{G} 7$ and G20 performance. Scholars focusing on summit performance critically depend on how compliance works. They assume that collective decisions or commitments do make a difference by being complied with relatively reliably and quickly after the summit ends. Compliance can 
even cause commitment, as countries are more likely to make commitments in the first place if they know others will comply rather than defect from or abandon the group [Ikenberry, 2001; $\mathrm{Li}, 2001]$. Those seeking to reform the summit process often claim a secretariat is needed for implementation and monitoring [Ikenberry, 1993].

Regarding commitments made at soft law, plurilateral summit institutions, the pioneering work of G. von Furstenberg and J. Daniels [1992] on the G7 found positive, if weak, compliance. They speculated that the key causes were a member's relative capability and domestic presidential or parliamentary political system. Q. Li [2001] later looked at the defection dynamics arising from interstate interactions in an anarchic, competitive system. He found that defection by one member was likely to breed defection by others and thus lower compliance overall. His argument was based on realist assumptions but added the liberal institutionalists' institutional iteration or game theorists' repeated games. J. Kirton [1989] emphasized informal international institutionalization. In contrast to the old multilateral organizations with entrenched bureaucracies and pathologies, informal, plurilateral, leader-level bodies have the flexibility to integrate anything they want in any way they want and to make sure the resulting commitments are complied with in the domestic hierarchy at home. E. Kokotsis [1999] thus developed a democratic institutionalist model highlighting the impact of two causes: a G7 ministerial meeting on the same subject as the commitment and the relative power of the responsible department with the members' government executive branch. Li [2001] also claims that state structure shapes compliance. He found that independent central banks "correlate positively with compliance on inflation-control commitments" and "some evidence that divided/coalition governments and uncertainty reduces compliance" [Ibid.]. R. Putnam [1988] offers a model of bureaucratic bargaining in which dominant coalitions of international and domestic actors create "win sets" to have the summit leaders agree to what the winning coalition wants. Yet those emphasizing individual agency suggest that compliance is controlled by the political will of the leaders who craft their commitments in a way that they want [Kirton, 2006; Kirton, Kokotsis, 2007; Kirton, Roudev, Sunderland, 2007].

Work led by J. Kirton and M. Larionova [Kirton, Larionova, 2018a] then tested many other causal candidates at several levels of analysis and found some that had specific compliance-improving or inhibiting impacts. This study extends these analyses to the summit of the new, more diverse and larger G20 to see if the most promising G7 compliance causes and accountability measures apply to G20 compliance and the compliance of its members belonging to the component clubs of the G7 and the BRICS grouping of Brazil, Russia, India, China and South Africa.

\section{Commitment Volume}

This study hypothesizes that the number of companion commitments is positively correlated with compliance. There are several plausible theories that may lead to this statistical relationship. First, a higher number of commitments may indicate or provoke a sense of urgency and importance at the summit among national leaders, pushing them to comply more afterwards. Second, as companion commitments within each issue area are interrelated, complying with one commitment may create a positive spillover effect encouraging compliance with the other commitments. Finally, a higher number of commitments may enhance compliance because isolated, individual commitments are narrowly defined and provide specific requirements and directions for the leaders. At the same time, if leaders face too many competing goals and commitments at the same time they may be forced to concentrate only on the most pressing issue which may lead to lower compliance overall. 


\section{Ministerial Meetings}

The second hypothesis, tested at both the summit and the commitment level, is that more ministerial meetings held during a summit year will enhance summit compliance. The ministers responsible for the specific policy area who meet before, during or after the summit perhaps implement and monitor compliance with the corresponding commitments or craft the commitments in a way that they know they will be able to comply with before the next summit [Kirton, Larionova, 2018b]. Denser networks resulting from frequent ministerial meetings may also lead to more information sharing and policy coordination. A.-M. Slaughter argues that "the simple fact of a meeting drives a desire to have some notable outcome" [cited in Cormier, 2018]. This implies that more meetings between summits will create more opportunities for ministers to coordinate policy and thus comply with the commitments [Cormier, 2018].

\section{Catalysts}

The third hypothesis is that the presence of a particular catalyst in a commitment increases compliance with it. Catalysts are specific words or directions embedded into commitments by leaders with the purpose of enhancing compliance [Kirton, Larionova, 2018b]. Catalysts provide guidance about how to comply with the precise, future-oriented, politically obligatory commitment. Some catalysts inhibit compliance and should be avoided [Kirton, Larionova, 2018b]. An earlier study by Larionova [2018] assessed the effect of catalysts on compliance in the nine G20 summits. She found that the average compliance for commitments containing catalysts was lower than for those without catalysts [Larionova, Rakhmangulov, Shelepov, 2018]. Even though most individual catalysts had a negative impact on compliance, self-accountability measures and timelines embedded into a commitment tended to improve compliance [Ibid.]. Evidence from G7/8 summits suggested that compliance tended to increase with use of catalysts such as a one-year timetable, core international organizations and priority placement; compliance tended to decrease when commitments include reference to another international organization, a multi-year timetable or a reference in a non-finance/development commitment to a G7 finance ministerial meeting and international law [Kirton, Larionova, 2018b].

\section{Hegemony, Reciprocity or Component Clubs}

The second part of this study addresses the compliance effects of the hegemony, reciprocity and component clubs within the G20. According to the theory of hegemonic stability, the most powerful countries influence the actions of the weaker countries [Keohane, 1984]. In the post-1945 liberal order, the United States had ultimate economic and political power and predominantly shaped international institutions [Cormier, 2018]. Today, the power of the U.S. has declined but may still influence the agenda of, and cooperation in, the G20. Recently, China has experienced tremendous economic growth and may become a new superpower and new potential hegemonic leader, in particular among the emerging economies. In the G20, the "follow the leader" variant of the hegemony hypothesis predicts that when the United States or China complies at a particular level, all others will also comply. The bi-hegemony hypothesis predicts that when both the United States and China comply, other countries react to their joint power and comply at about their level.

An alternative theory is that of reciprocal compliance. It hypothesizes that any member, not only the most powerful, can influence compliance. Institutionalist theories claim that the success of informal institutions such as the G7/8 and the G20 is a product of cooperation and 
reciprocity, not coercion or free riding [Cormier, 2018]. B. Cormier [2018] found that the G7/8 summit indeed acted as a reciprocal group - each member's compliance was similar to that of other members, while U.S. compliance correlated the least to the compliance of the other G7 members.

\section{Methods}

\section{Data}

At the 12 G20 summits from Washington in 2008 to Hamburg in 2017, G20 leaders made a total of 2,398 commitments. Over $10 \%$ (243) were assessed for compliance by the G20 Research Group and the Center for International Institutions Research. Compliance is assessed on a three-point scale: non-compliance $(-1)$, partial compliance $(0)$ and full compliance $(+1)$. Overall compliance with the 243 assessed G20 commitments averaged $71.5 \%$ (or +0.43 on the scientific scale).

\section{Statistical Analyses}

First, this study examined how the number of commitments made at each summit correlated with the members' subsequent compliance with them (see Appendix A). The correlation coefficients between the number of commitments and average compliance with the assessed commitments were estimated for overall summit compliance, country-specific compliance and subject-specific compliance.

Second, this study calculated the correlations between the number of ministerial meetings held in the same summit period and compliance with the commitments made at that period's summit. The relationship between the ministerial meetings and subject-specific compliance was tested for six issue areas: food and agriculture, labour and employment, macroeconomic policy, financial regulation, trade and energy. Correlations between the number of ministerial meetings and the number of commitments were also considered.

Third, the compliance impact of the catalysts contained in each commitment was assessed. Of the 22 known catalysts, only 18 were found in the 243 commitments that had been assessed for compliance. The catalysts "past reference to ministerial," "international organization accountability request," "surveillance" and "international organizations surveillance" were not included in any of the 243 commitments. The distribution of the included catalysts was as follows: 108 commitments contained no catalysts; 76 commitments contained one catalyst; 41 commitments contained two catalysts; nine commitments contained three catalysts; five commitments contained four catalysts; two commitments contained five catalysts; and two commitments contained six catalysts. The statistical significance of each catalyst was initially considered in isolation with a t-test (see Appendix C-1). Then, ordinary least squares (OLS) regression was used to estimate the impact of the catalysts on compliance. To avoid overfitting, the best fit model was identified using adjusted R-squared and AIC criteria. It included five catalysts: multi-year timetable, self-monitoring, other international organization, ministers and country or region.

To test for ministerial reinforcement at the commitment level, the dummy variable "ministerial meeting" was added to the OLS model, indicating whether a pre-summit ministerial meeting on a subject corresponding to that of the commitment was held in that summit period.

The country-specific compliance effects of the catalysts were then estimated with an ordinal logistic regression model. Compliance was measured on a three-point scale. The results 
report the change in the predicted likelihood of full compliance $(+1)$ in the presence of each catalyst that was statistically significant.

To find evidence for either hegemonic or reciprocally driven compliance, this study observed the trends in compliance correlations among G20 members. The correlations were calculated for each pair of countries. The total number of pairs between members was 190 (see Appendix F).

Then the effects of hegemony, reciprocity and component clubs within the G20 were tested in the context of the effects of the similarity in growth of gross domestic product (GDP) and the democracy level of each member. In the OLS regression model each observation was a correlation of the compliance of a pair of countries. The number of observations was 190 , equal to the number of unique pairs of countries. The following variables were included in the regression model.

\section{Internal Economic Factors}

First, to test if similarity in economic growth was a significant cause of similar compliance, a GDP growth measure for each country in a given summit year was used. Overall, higher economic growth does not result in higher compliance with commitments. Yet having similar GDP growth may lead countries to comply with the same commitments. For example, when growth is higher it may be easier to reduce fiscal deficits or unemployment and thus comply with commitments to do so. Using World Bank GDP growth data, the correlations of each member's GDP growth with every other member were estimated [World Bank, 2018]. The continuous variable of "GDP correlations" was used in the model.

\section{Internal Political Factors}

Second, democratic governments might comply with the same commitments as other democratic governments, whereas non-democratic governments might comply with the same commitments as other non-democratic governments. To approximate political similarity the Freedom House Democracy Index was used [Freedom House, 2018]. The variable "Democracy" for the freedom index was equal to 1 if both countries were free/not-free and was equal 0 if countries had different scores in a given year.

\section{Component Clubs}

Being a member of other international institutions such as the G7, BRICS or European Union (EU) may explain the similarity in G20 members' compliance with their G20 commitments. Leaders and ministers of the G7 and BRICS meet plurilaterally more often than leaders and ministers of the remaining G20 members. As noted before, this may result in stronger international networks and cooperation and even lead to coordination of their G20 commitment production and compliance. To test if membership in the G7, BRICS or EU determined similarity in compliance, three dummy variables were used to indicate the correlations within the G7, BRICS and EU. That is, if a compliance correlation corresponded to a pair of countries that were both members of the G7 (including the EU), the variable "G7" would be equal to 1 , and to 0 in all other cases. Similarly, "BRICS" and "EU" variables were equal to 1 when correlations corresponded to pairs of countries that were both members of these groups. EU countries included France, Italy, Germany, the UK and the EU. 


\section{Hegemonic Leader}

To test if hegemony has an impact in this model, two binary variables were included to indicate the correlations of G20 members' compliance with that of the U.S. and China. These variables divided the observations into two groups to test if compliance of the members was more similar to the compliance of the U.S. or China than to the compliance of the remaining countries. The variable "USA" was equal to 1 for compliance correlations of the U.S. with each other G20 member, and 0 for the remaining cases. Similarly, the variable "China" was equal to 1 for the compliance correlations of China with each other G20 member, and 0 in the remaining cases. If there is evidence of the hegemonic power and thus leadership of either one of these most powerful countries, the correlations of compliance will be higher for members' correlations with these two states than for all other correlations.

The regression equation was:

$$
\begin{gathered}
\text { Compliance corr }=\text { constant }+\beta_{1} \text { corrGDP }+\beta_{2} \text { Democracy }+ \\
+\beta_{3} \text { BRICS }+\beta_{4} E U+\beta_{5} G 7+\beta_{6} U S A+\beta_{7} \text { China }
\end{gathered}
$$

(see Appendix H).

The effect of the "G2" bi-hegemony compliance on each member's compliance was tested using ordinal logistic regression models. An interaction term was added to the model to test if the joint compliance or non-compliance of the G2 had a significant effect on the compliance of each other member. For simplicity in interpretation, the compliance scores of the U.S. and China were converted from the three-point scale to a dummy variable equal to 1 if compliance was +1 , and equal to 0 if it was -1 or 0 . A total of 18 regression equations, one for each of the remaining G20 members, were used:

$$
\text { Country } i \text { compliance }=\text { constant }+\beta_{1} \text { China }+\beta_{2} U S+\beta_{3} \text { China } \times U S+\text { remaining members }
$$

(see Appendix G). The reported results are the changes in the probabilities that a country fully complies given that China fully complied, the U.S. fully complied and both China and the U.S. fully complied.

\section{Results}

\section{Number of Commitments at Summit for Overall Compliance}

The average number of commitments made at each of the 12 G20 summits was 200 . The average compliance of members with the assessed commitments made at summits with fewer than 200 commitments was $6 \%$ lower at $68.5 \%(+0.37)$ than the average compliance for summits with more than 200 commitments at $75 \%(+0.50)$. Sixteen of the 20 members had higher compliance when the number of commitments went up. However, due to the small sample size, this relationship was statistically significant only for Canada, India and the EU. South Africa, Turkey, the UK and the U.S. were the exceptions to this trend, with their lower compliance corresponding to a higher number of commitments. There was thus a weak positive relationship between the number of commitments and the average compliance with the assessed ones. However, the limited sample size of 12 summits does not allow one to isolate with confidence the causal impact on compliance of the number of commitments. 


\section{Number of Commitments at Summit for Subject-Specific Compliance}

The relationship between the number of commitments on a specific subject at a summit and the average compliance of members with the assessed commitments on that subject differed from one subject to another. On energy, there was a strong, positive, statistically significant relationship, suggesting that more commitments may lead to higher compliance. The correlation coefficient was equal to +0.61 . On agriculture, labour, trade, macroeconomic policy and financial regulation commitments no statistically significant effect was found (see Appendix B).

\section{Number of Ministerial Meetings Before and After Summit for Overall Compliance}

There was a positive relationship between the number of meetings of finance ministers and central bank governors before the summit and the average compliance with the summit commitments overall. Moreover, a higher total number of ministerial meetings responsible for all policy areas held before the summit also led to improved compliance (see Appendix A). In particular, Argentina, India and Mexico tended to improve compliance the most in response to pre-summit ministerial meetings. In contrast, the UK's compliance decreased when the number of ministerial meetings increased.

To estimate the relationship for the ministerial meetings held after the summit, each ministerial meeting was lagged by one year so that it was paired with the summit held the year before. The positive effect of ministerial meetings on compliance did not hold for the meetings held after the summit. This may imply that ministers enhance compliance by crafting commitments that are easy to comply with in advance and not by enhancing compliance through following up on their progress. However, the above estimate should be treated with caution because most of these meetings were officially associated with the next summit year and its new summit host and should not be treated as meetings to follow up the previous summit. Moreover, with the sample size of 12 summits, the varying time of the year in which each was held and the varying interval between them, it is too early to conclude that the ministerial institutions play a significant role in enhancing compliance.

\section{Ministerial Meetings Before Summit for Number of Subject-Specific Commitments}

There was a strong, positive, significant relationship between the number of ministerial meetings held before the summit and the number of commitments made at the summit. The correlation coefficient is equal to +0.62 and is significant at $5 \%$. The number of meetings of finance ministers and central bank governors in each summit year was positively correlated with the number of macroeconomic commitments at that summit. This relationship is statistically significant and the correlation coefficient is equal to +0.61 . However, a higher number of meetings of finance ministers and central bank governors did not influence the number of commitments made on financial regulation which could be prepared within the more specifically focused Financial Stability Forum or Board. Perhaps this result is driven by the fact that other actors are responsible for financial regulation within countries, whereas finance ministers and central bank governors are directly responsible for macroeconomic policy. Labour ministerial meetings tended to have a significant effect on the number of labour commitments made at each summit; the correlation coefficient is +0.67 and is significant at $5 \%$. Energy, trade and agricultural ministerial meetings did not have a significant effect on the number of summit commitments made on each of these subjects (see Appendix B). 


\section{Ministerial Meetings Before Summit for Subject-Specific Compliance}

Analysis by subject calls into question the previous finding that more ministerial meetings tend to enhance compliance. But energy compliance was lower for summits when energy ministerial meetings were held. Trade ministerial meetings did tend to have a weak positive effect on compliance. There is no statistically significant relationship in food and agriculture, labour and employment, macroeconomic or financial regulation compliance (see Appendix B). The sample sizes for subject-specific compliance are small. Therefore, these results are insufficient to draw a definitive, as distinct from a suggestive, conclusion about the role of ministerial meetings in enhancing compliance.

\section{Catalysts in Commitments}

This section reports the impact of the substantive compliance catalysts that were embedded in the commitments and are thought to either improve or hinder compliance [Kirton, Larionova, 2018b]. Overall, the average compliance with commitments containing at least one catalyst was lower than compliance with commitments without catalysts. Compliance was equal to $77 \%(0.53)$ for commitments without catalysts, $69 \%(0.39)$ for commitments with one catalyst, $68 \%(0.36)$ with two catalysts, $66 \%(0.32)$ with three catalysts, $64 \%(0.28)$ with four catalysts, $69 \%(0.38)$ with five catalysts and 50\% (0.00) with six catalysts (see Appendix C-2). A "shotgun approach" of including many different catalysts in a commitment thus does not work if enhancing compliance is the goal.

Regarding specific catalysts, a correlation analysis showed that in isolation most catalysts had no statistically significant effect on compliance. Reference to ministers was the only statistically significant catalyst that enhanced compliance. Lowering compliance were multi-year timetables, requests for self-monitoring, a reference to other international organizations and regional organizations and a reference to a specific country or region (see Appendix C-1).

References to ministers responsible for a specific issue increased compliance by $23 \%$ (0.46). In sharp contrast, the presence of multi-year timetable in a commitment lowered compliance by $7.3 \%$ ( 0.15 points). A reference to another international organization lowered compliance by $21 \%(0.42)$. A reference to a specific country or region lowered compliance by $17 \%$ (0.34). A reference to self-monitoring lowered compliance by $20 \%(0.41)$. This model explains only $10 \%$ of the variation in compliance, meaning that there are other significant factors that affect compliance (see Appendix D).

The results of a multiple regression with compliance catalysts and a dummy variable indicating that a pre-summit ministerial meeting was held show that the presence of at least one ministerial meeting before the summit enhanced compliance by $9 \%$ ( 0.18 points). This regression added an additional 5\% to the explanatory power of the previous model (see Appendix D).

The effect of catalysts on compliance varied by country (see Appendix E). Ordinal logistic regression predicted only two cases with significant positive effects. The minister-reference catalyst increased the probability that Brazil would fully comply by $47 \%$. The targets catalyst increased the probability that Italy would fully comply by $15 \%$.

There were far more cases with significant negative effects. Numeric targets embedded in commitments reduced the probability that Argentina would fully comply by $28 \%$. A reference to a specified agent decreased Canada's likelihood of full compliance by $22 \%$, India's by $22 \%$ and Saudi Arabia's by $16 \%$. Multi-year timetables decreased Germany's likelihood of full compliance by $21 \%$, India's by $22 \%$, Italy's by $8 \%$, Turkey's by $25 \%$, the United States' by $26 \%$ and the EU's by $14 \%$. A reference to self-monitoring decreased Germany's likelihood of full compliance by $46 \%$ and the UK's by $37 \%$. A reference to other international organizations low- 
ered Germany's likelihood of full compliance by $36 \%$. A reference to money-mobilized lowered India's likelihood of full compliance by $39 \%$. A reference to international law lowered India's likelihood by $27 \%$. A reference to the private sector decreased Mexico's probability of full compliance by $33 \%$. One-year timetables decreased the EU's likelihood of full compliance by $23 \%$ (see Appendix E). Overall, commitments that did not contain any catalysts performed better. Multi-year timetables tended to be the most common inhibitor.

In all, it seems that compliance increases when members are given greater freedom about how, how much and when they will comply. Catalyst-free commitments work best to improve compliance.

\section{Hegemony, Reciprocity and Component Clubs}

Does any G20 member's compliance affect the other members' compliance? This section reports the trends in compliance correlations among the G20 members. The results tend to confirm the reciprocity hypothesis. They show particularly strong similarity among the G7 and BRICS members' compliance with one another. The average correlation for all countries' compliance is +0.30 . This indicates a positive but weak relationship among all countries' compliance performances. The average correlation of the United States' compliance with other countries is only +0.27 . This means that it is unlikely that the U.S. influenced other countries' compliance in either a positive or a negative way. The average correlation of China's compliance with other countries is +0.33 . This is only slightly greater than the average of all countries and that of the United States. Therefore, it does not seem that China is a hegemonic leader in the G20, in either a positive beneficent way (by bearing a greater share of the compliance burden) or a negative, coercive way (by counting on others to comply while it takes a "free ride").

In the case of component clubs, G7 countries' compliance scores (including the EU) are substantially correlated with one another. Their average compliance correlation is +0.37 . Yet the United States' compliance with other G7 countries is correlated the lowest compared to other members, so the hypothesis of the hegemonic power of the U.S. is not supported even with its smaller, like-minded, democratic G7 club.

Within the G7, the EU countries' (France, Germany, Italy, the UK, the EU) compliance correlation is +0.40 . This is significantly higher than the +0.30 for all G20 countries. The hard law, semi-supranational, regional EU with its large secretariat and frequent summit meetings seems to help its members comply in the bigger, broader, more diverse, global G20.

The BRIC (South Africa excluded) countries have substantial correlations with one another. Their average correlation is equal to +0.39 . BRICS' average correlation is +0.35 . South Africa's compliance is not very well correlated with any other country's compliance. Its highest correlations are +0.37 with Mexico and +0.31 with China. The BRICS countries have lower than average correlations with the G7 countries, at +0.23 . South Africa's correlation with $G 7$ countries is +0.21 , Brazil's is +0.22 , China's is +0.30 , India's is +0.19 and Russia's is +0.22 . BRICS' practice of holding an intersessional summit hours before the G20 meeting at the summit site seems to impact compliance of BRICS members in the larger G20 group.

The correlation analysis suggests that the compliance of individual members within the G20 was determined by their membership in other smaller clubs, notably the G7, BRICS and above all the EU. Possibly, governments that are more interconnected, share common values of democracy and are highly interdependent (as G7 and EU members are) follow one another in their G20 compliance. Another plausible explanation for this finding is the homogeneity of the G7, BRICS and EU members as opposed to the heterogeneity of G20 members. The G7, EU and BRICS members have relatively similar economic and political structures. For example, G7 members have experienced relatively low economic growth, have high GDP per capita, and 
are stable democracies. BRICS countries have experienced higher economic growth on average, have lower GDP per capita, and China and Russia have non-democratic regimes. Therefore, it may be easier for each of these groups to comply with the same commitments because of the lower political and economic costs of implementing similar policies.

\section{Hegemony, Reciprocity and Clubs Amidst Controls}

Is the similarity in compliance driven by internal structural factors of members or by external international factors such as being members of the G7, the BRICS or the EU?

The results of the regression model with the control variables of GDP growth and democracy levels further disconfirm the hegemonic leader hypothesis. G20 members have significantly lower compliance correlations with the U.S. than with the other members. Each member's compliance similarity with China is not significantly different from its compliance similarity with other members. Therefore, this model confirms that the G20 acts as a reciprocal group. However, the correlations among EU members and BRICS members stand out. The compliance of these groups' members is more aligned than the overall reciprocal relationship in the G20. Moreover, these two groups do not comply together. They comply highly with different commitments. The above model suggests that the causes of the similarity in members' compliance are related to the external international factors of small club membership rather than the internal differences in members' economic or political structures. A potential explanation for higher compliance similarity within clubs may be that members of the G7 and BRICS now meet more often or at more regular intervals than the G20 as a whole, resulting in stronger networks of national leaders to foster cooperation. In addition, these two groups may compete in the G20 for influence on the global stage and to advance their different versions of world order.

Democracies have higher compliance than non-democratic governments. Yet the latter often comply with the same commitments as democratic governments and the governments with the same democracy score often comply with different ones. This variable may not be a good approximation for internal political systems because most governments in the G20 are democratic. Only China, Saudi Arabia and now Russia and Turkey are not. A better approximation for political similarity may be defining governments' political ideology on a right-wing to left-wing scale. Another limitation of this model is the fact that there may be other significant structural factors that have not been taken into account. For example, in trade commitments, the balance of trade may be a significant determinant of compliance. For climate change commitments, a country's dependence on fossil fuels may be important.

\section{G2 Hypothesis}

In isolation, neither the U.S. nor China appears to exercise hegemonic power on compliance in the G20. Yet while the rest of the G20 is not influenced by only one alone, they may be influenced by the two together. The ordinal logistic regression predicted the probabilities of each country to fully comply in three scenarios.

\section{If Only the United States Complied}

When the U.S. complied, Canada's likelihood to fully comply increased by $14 \%$ from $74 \%$ to $88 \%$. India's increased by $13 \%$ from $50 \%$ to $63 \%$. Compliance by the U.S. had no significant effect on any other countries' compliance. 


\section{If Only China Complied}

When China complied, three countries significantly increased their compliance. Canada's likelihood to fully comply increased by $18 \%$ from $74 \%$ overall to $92 \%$ when China fully complied. India's increased by $22 \%$ from $50 \%$ to $72 \%$. Indonesia's by increased by $16 \%$ from $41 \%$ to $57 \%$.

\section{Joint Effect}

For most country-specific effects, the "G2" interactive term was not significant in this model. When both China and the U.S. complied Russia's likelihood to fully comply increased by $24 \%$ from $46 \%$ to $70 \%$. Turkey's increased by $22 \%$ from $38 \%$ to $60 \%$.

Although there were a few cases where the U.S. and China had a significant effect on individual countries' compliance, their effects did not stand out among all other countries' effects on one another. The majority of the regression coefficients were positive, indicating that most countries comply together. Therefore, the hypothesis about joint G2 hegemonic leadership is disconfirmed. The overall tendency of countries was to have reciprocal compliance, as described in the previous section. In its compliance, the G20 is a group of equals rather than one led by the U.S., China or both.

\section{Conclusion}

In sum, the number of commitments made at a summit tends to correlate with higher compliance with them. The relationship is strong at the overall summit level, but subject-specific effects are uncertain. This finding supports the hypothesis that more summit commitments lead to or reflect the leaders' recognition of the summit's importance, thus inducing them to dedicate resources to comply. With the limited sample size of only 12 summits, and thus the inability to confidently isolate causal effect, more research is needed to confirm or refute the hypothesis about the role of the commitment volume.

At the summit level, although mixed evidence emerged elsewhere for the effect of the G20, more financial ministers and central bank governor meetings enhance compliance in all policy areas. At the commitment level, holding at least one pre-summit ministerial meeting corresponding to a specific policy area in a summit year tended to significantly improve compliance. Moreover, the minister-reference catalyst was the only catalyst that improved compliance.

Embedding compliance catalysts into commitments largely hindered compliance. In particular, the catalysts of a multi-year timetable, self-monitoring, a reference to other international organizations and a reference to a country or region were statistically significant compliance inhibitors. There was some variation in country-specific effects that may reflect the differences in countries' priorities or capacities. Even though this study finds some strong evidence against the use of catalysts in the commitments, the results may differ for each specific subject area. For instance, A. Wang [2018] found that G20 performance in economic governance was improved when commitments with specific timetables and references to countries or regions were used in macroeconomic and microeconomic commitments.

Finally, members of the G20 operate as equals, as members of a reciprocal group. This disconfirms the hegemonic compliance hypothesis. Neither the U.S., nor China, nor both, tended to influence the compliance of the remaining members. Similarity in G20 compliance is particularly high among members of the EU, G7 and BRICS as component clubs. The causes of this similarity appear to be international factors of the membership in the smaller clubs rather than the similarity in their economic growth or levels of democracy. 
This study thus adds insights to the emerging literature on the accountability measures that can improve compliance in the G20 [Hilbrich, Schwab, 2018; Kirton, Larionova, 2018b]. Yet the results rely on the member consensus, collective acceptance assumption that may not necessarily hold. The results also face the challenges of potential confounding factors. More research is needed on accountability measures and other potential causes of compliance. In particular, future studies should aim to isolate the causal impact of the known accountability measures.

There are also several possibilities for future research to explore how independently specified members' interests affect their compliance with G20 or other summits' commitments. First, researchers could test if partial commitments that explicitly exclude the U.S. from being bound by them are complied with more than those that equally bind all members. Second, future studies could account for the priorities a member set when it hosted a G20/G7/BRICS summit and assume that these priorities substantially endured in all the summits it attended. Third, future studies could test if summit compliance increased when a specific commitment issue was identified as an important issue in that member's national policy address presented prior to the summit (for example, the U.S. State of the Union address). Finally, a member's reaction to a commitment (initiate/support/acquiesce/oppose) in summit preparations and negotiations could be considered when such detailed evidence reliably exists.

\section{References}

Cicci A. (2018) G20 Performance on Financial Stability. G20 Argentina: The Buenos Aires Summit (J. Kirton, M. Koch (eds)). London: GT Media Group Ltd.

Cormier B. (2018) Explaining G8 Compliance: Reciprocity, Ministerial Institutionalization and Accountability. Accountability and Effectiveness in Global Governance (J. Kirton, M. Larionova (eds)). Abdingdon: Routledge.

Freedom House (2018) Freedom in the World 2018: Democracy in Crisis. Available at: https://freedomhouse. org/report/freedom-world/freedom-world-2018 (accessed 12 November 2018).

von Furstenberg G., Daniels J. (1992) Can You Trust G-7 Promises? International Economic Insights, vol. 3 (September/October), pp. 24-7.

Hallink C. (2018) G20 Performance on Development. G20 Argentina: The Buenos Aires Summit (J. Kirton, M. Koch (eds)). London: GT Media Group Ltd.

Hilbrich S., Schwab J. (2018) Towards a More Accountable G20? Accountability Mechanisms of the G20 and the New Challenges Posed to Them by the 2030 Agenda. International Organizations Research Journal, vol. 13, no 4, pp. 7-38.

Ikenberry J. (1993) Salvaging the G7. Foreign Affairs, vol. 72 (Spring), pp. 132-9.

Ikenberry J. (2001) After Victory: Institutions, Strategic Restraint, and the Rebuilding of Order after Major Wars. Princeton: Princeton University Press.

Keohane R.O. (1984) After Hegemony: Cooperation and Discord in the World Political Economy. Princeton: Princeton University Press.

Keohane R.O. (2006) Accountability in World Politics. Scandinavian Political Studies, vol. 29, no 2, pp. 75-7.

Keohane R.O. (2011) Global Governance and Legitimacy. Review of International Political Economy, vol. 18, no 1, pp. 99-109.

Kirton J. (1989) Contemporary Concert Diplomacy: The Seven-Power Summit and the Management of International Order. Paper presented at the Annual Convention of the International Studies Association, London, 29 March - 1 April. Available at: www.g8.utoronto.ca/scholar/kirton198901 (accessed 12 November 2018).

Kirton J. (2006) Explaining Compliance with G8 Finance Commitments: Agency, Institutionalization and Structure. Open Economies Review, vol. 17 (November), pp. 459-75. 
Kirton J., Kokotsis E. (2007) Keeping Faith With Africa's Health: Catalysing G8 Compliance. Governing Global Health: Challenge, Response, Innovation (A. Cooper, J. Kirton, T. Schrecker (eds)). Aldershot: Ashgate.

Kirton J., Larionova M. (eds) (2018a) Accountability for Effectiveness in Global Governance. Abingdon: Routledge.

Kirton J., Larionova M. (2018b) Accountability for Effectiveness in Global Governance. Accountability and Effectiveness in Global Governance (J. Kirton, M. Larionova (eds)). Abingdon: Routledge.

Kirton J., Roudev N., Sunderland L. (2007) Making Major Powers Deliver: Explaining Compliance with G8 Health Commitments, 1996-2006. Bulletin of the World Health Organization, vol. 85, no 3 (March), pp. 192-9.

Kokotsis E. (1999) Keeping International Commitments: Compliance, Credibility, and the G7, 1988-1995. New York: Garland.

Kokotsis E. (2018) G20 Performance on Climate and Energy. G20 Argentina: The Buenos Aires Summit (J. Kirton, M. Koch (eds)). London: GT Media Group Ltd.

Kulik J. (2018) G20 Performance on Gender Equality. G20 Argentina: The Buenos Aires Summit (J. Kirton, M. Koch (eds)). London: GT Media Group Ltd.

Larionova M., Rakhmangulov M., Shelepov A. (2018) Explaining G20 and BRICS Compliance. Accountability for Effectiveness in Global Governance (J. Kirton, M. Larionova (eds)). Abingdon: Routledge.

Li Q. (2001) Commitment Compliance in G7 Summit Macroeconomic Policy Coordination. Political Research Quarterly, vol. 54 (June), pp. 355-78.

Marchyshyn M. (2018) G20 Performance on Trade. G20 Argentina: The Buenos Aires Summit (J. Kirton, M. Koch (eds)). London: GT Media Group Ltd.

Motala M. (2018) G20 Performance on International Taxation. G20 Argentina: The Buenos Aires Summit (J. Kirton, M. Koch (eds)). London: GT Media Group Ltd.

Putnam R. (1988) Diplomacy and Domestic Politics: The Logic of Two-Level Games. International Organization, vol. 42, no 3, pp. 427-60.

Rudich D. (2018) G20 Performance on Countering Corruption. G20 Argentina: The Buenos Aires Summit (J. Kirton, M. Koch (eds)). London: GT Media Group Ltd.

Tops J. (2018) G20 Performance on Infrastructure Development. G20 Argentina: The Buenos Aires Summit (J. Kirton, M. Koch (eds)). London: GT Media Group Ltd.

Wang A. (2018) G20 Performance on Economic Governance. G20 Argentina: The Buenos Aires Summit (J. Kirton, M. Koch (eds)). London: GT Media Group Ltd.

Warren B. (2018a) G20 Performance on Climate Change. G20 Argentina: The Buenos Aires Summit (J. Kirton, M. Koch (eds)). London: GT Media Group Ltd.

Warren B. (2018b) G20 Performance on Food and Agriculture. G20 Argentina: The Buenos Aires Summit (J. Kirton, M. Koch (eds)). London: GT Media Group Ltd.

Wendt A. (1999) Social Theory of International Politics. Cambridge: Cambridge University Press.

Williams M. (2018) G20 Performance on Labour and Employment. G20 Argentina: The Buenos Aires Summit (J. Kirton, M. Koch (eds)). London: GT Media Group Ltd.

World Bank (2018) GDP Growth (Annual \%). World Development Indicators Database. Available at: https:// data.worldbank.org/indicator/NY.GDP.MKTP.KD.ZG?view=chart (accessed 12 November 2018). 


\section{Appendix A \\ Compliance, Number of Commitments and Ministerial Meetings by Summit}

\begin{tabular}{|c|c|c|c|c|c|c|c|c|c|c|c|c|c|}
\hline & हैं & 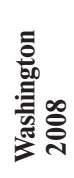 & 产 & 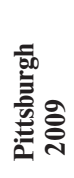 & 율을 & 施을 & 总 & 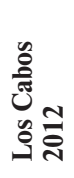 & 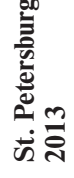 & 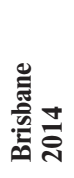 & 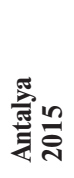 & 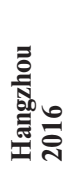 & 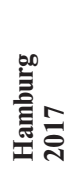 \\
\hline Total N Commitments & 2398 & 95 & 129 & 127 & 61 & 153 & 282 & 180 & 281 & 205 & 141 & 213 & 531 \\
\hline Commitments Assessed & 243 & 8 & 7 & 15 & 15 & 38 & 22 & 19 & 24 & 26 & 23 & 29 & 17 \\
\hline Overall Compliance & $\begin{array}{l}71 \% \\
0.42\end{array}$ & $\begin{array}{l}75 \% \\
0.50\end{array}$ & $\begin{array}{l}57 \% \\
0.14\end{array}$ & $\begin{array}{l}67 \% \\
0.34\end{array}$ & $\begin{array}{l}68 \% \\
0.36\end{array}$ & $\begin{array}{l}67 \% \\
0.34\end{array}$ & $\begin{array}{l}74 \% \\
0.47\end{array}$ & $\begin{array}{l}77 \% \\
0.54\end{array}$ & $\begin{array}{l}69 \% \\
0.38\end{array}$ & $\begin{array}{l}72 \% \\
0.43\end{array}$ & $\begin{array}{l}71 \% \\
0.41\end{array}$ & $\begin{array}{l}73 \% \\
0.45\end{array}$ & $\begin{array}{l}87 \% \\
0.75\end{array}$ \\
\hline $\begin{array}{l}\text { Total N Ministerial } \\
\text { Meetings }\end{array}$ & 66 & 2 & 1 & 2 & 3 & 4 & 8 & 8 & 8 & 7 & 9 & 8 & 6 \\
\hline $\begin{array}{l}\text { Finance Ministerial } \\
\text { Meetings }\end{array}$ & 40 & 2 & 1 & 2 & 3 & 3 & 6 & 3 & 6 & 5 & 4 & 4 & 1 \\
\hline $\begin{array}{l}\text { Agriculture Ministerial } \\
\text { Meetings }\end{array}$ & 4 & 0 & 0 & 0 & 0 & 0 & 1 & 1 & 0 & 0 & 0 & 1 & 1 \\
\hline $\begin{array}{l}\text { Energy Ministerial } \\
\text { Meetings }\end{array}$ & 2 & 0 & 0 & 0 & 0 & 0 & 0 & 0 & 0 & 0 & 1 & 1 & 0 \\
\hline $\begin{array}{l}\text { Foreign Ministerial } \\
\text { Meetings }\end{array}$ & 4 & 0 & 0 & 0 & 0 & 0 & 0 & 1 & 1 & 0 & 1 & 0 & 1 \\
\hline $\begin{array}{l}\text { Labour Ministerial } \\
\text { Meetings }\end{array}$ & 8 & 0 & 0 & 0 & 0 & 1 & 1 & 1 & 1 & 1 & 1 & 1 & 1 \\
\hline $\begin{array}{l}\text { Tourism Ministerial } \\
\text { Meetings }\end{array}$ & 2 & 0 & 0 & 0 & 0 & 0 & 0 & 1 & 0 & 0 & 1 & 0 & 0 \\
\hline $\begin{array}{l}\text { Trade Ministerial } \\
\text { Meetings }\end{array}$ & 4 & 0 & 0 & 0 & 0 & 0 & 0 & 1 & 0 & 1 & 1 & 1 & 0 \\
\hline $\begin{array}{l}\text { Health Ministerial } \\
\text { Meetings }\end{array}$ & 1 & 0 & 0 & 0 & 0 & 0 & 0 & 0 & 0 & 0 & 0 & 0 & 1 \\
\hline $\begin{array}{l}\text { Digitalization } \\
\text { Ministerial Meetings }\end{array}$ & 1 & 0 & 0 & 0 & 0 & 0 & 0 & 0 & 0 & 0 & 0 & 0 & 1 \\
\hline
\end{tabular}




\section{Appendix B}

Compliance, Number of Commitments and Ministerial Meetings by Subject Area

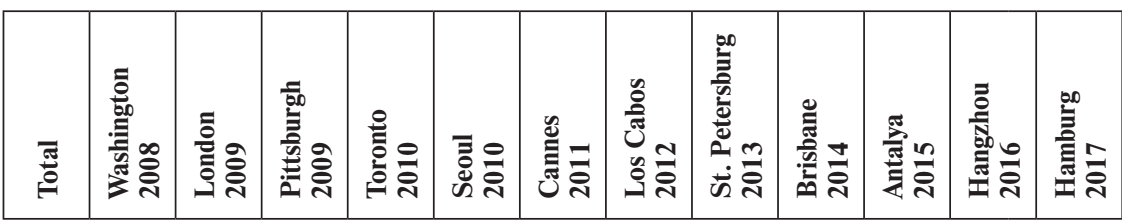

Food and Agriculture

\begin{tabular}{|c|c|c|c|c|c|c|c|c|c|c|c|c|c|}
\hline N Commitments & 114 & 0 & 0 & 3 & 2 & 2 & 36 & 4 & 11 & 0 & 31 & 3 & 22 \\
\hline $\begin{array}{l}\text { N Commitments } \\
\text { Assessed }\end{array}$ & 7 & 0 & 0 & 0 & 1 & 0 & 1 & 2 & 1 & 0 & 1 & 0 & 1 \\
\hline Overall Compliance & $\begin{array}{l}77 \% \\
0.54\end{array}$ & & & & $\begin{array}{c}100 \% \\
1\end{array}$ & & $\begin{array}{l}78 \% \\
0.55\end{array}$ & $\begin{array}{l}68 \% \\
0.35\end{array}$ & $\begin{array}{c}90 \% \\
0.8\end{array}$ & & $\begin{array}{l}45 \% \\
-0.1\end{array}$ & & $\begin{array}{c}85 \% \\
0.7\end{array}$ \\
\hline $\begin{array}{l}\mathrm{N} \text { of Ministerial } \\
\text { Meetings }\end{array}$ & 4 & 0 & 0 & 0 & 0 & 0 & 1 & 1 & 0 & 0 & 0 & 1 & 1 \\
\hline
\end{tabular}

Energy

\begin{tabular}{|l|c|c|c|c|c|c|c|c|c|c|c|c|c|}
\hline N Commitments & 142 & 0 & 0 & 16 & 1 & 14 & 18 & 10 & 19 & 16 & 3 & 8 & 42 \\
\hline $\begin{array}{l}\text { N Commitments } \\
\text { Assessed }\end{array}$ & 21 & 0 & 0 & 4 & 1 & 2 & 5 & 1 & 1 & 2 & 1 & 3 & 1 \\
\hline Overall Compliance & $68 \%$ & & & $71 \%$ & $73 \%$ & $76 \%$ & $71 \%$ & $79 \%$ & $78 \%$ & $62 \%$ & $33 \%$ & $55 \%$ & $93 \%$ \\
& 0.37 & & & 0.42 & 0.45 & 0.51 & 0.42 & 0.58 & 0.55 & 0.24 & -0.35 & 0.1 & 0.85 \\
\hline $\begin{array}{l}\text { N of Ministerial } \\
\text { Meetings }\end{array}$ & 2 & 0 & 0 & 0 & 0 & 0 & 0 & 0 & 0 & 0 & 1 & 1 & 0 \\
\hline
\end{tabular}

Labour and Employment

\begin{tabular}{|c|c|c|c|c|c|c|c|c|c|c|c|c|c|}
\hline N Commitments & 126 & 0 & 4 & 3 & 0 & 4 & 8 & 18 & 29 & 16 & 10 & 9 & 25 \\
\hline $\begin{array}{l}\text { N Commitments } \\
\text { Assessed }\end{array}$ & 18 & 0 & 0 & 0 & 0 & 0 & 2 & 1 & 7 & 2 & 4 & 2 & 0 \\
\hline Overall Compliance & $\begin{array}{l}77 \% \\
0.54\end{array}$ & & & & & & $\begin{array}{l}74 \% \\
0.47\end{array}$ & $\begin{array}{c}100 \% \\
1\end{array}$ & $\begin{array}{l}88 \% \\
0.75\end{array}$ & $\begin{array}{l}89 \% \\
0.78\end{array}$ & $\begin{array}{l}67 \% \\
0.33\end{array}$ & $\begin{array}{l}51 \% \\
0.03\end{array}$ & \\
\hline $\begin{array}{l}\mathrm{N} \text { of Ministerial } \\
\text { Meetings }\end{array}$ & 8 & 0 & 0 & 0 & 0 & 1 & 1 & 1 & 1 & 1 & 1 & 1 & 1 \\
\hline
\end{tabular}

\begin{tabular}{|c|c|c|c|c|c|c|c|c|c|c|c|c|}
\hline हैं & 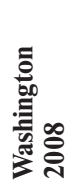 & 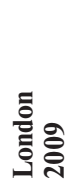 & 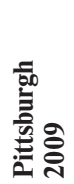 & 을 & 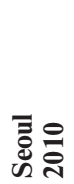 & 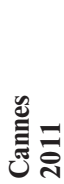 & 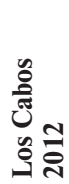 & 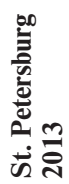 & 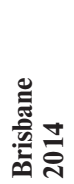 & 宽是 & 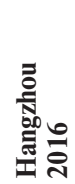 & 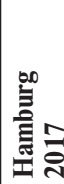 \\
\hline
\end{tabular}

Macroeconomics

\begin{tabular}{|l|c|c|c|c|c|c|c|c|c|c|c|c|c|}
\hline N Commitments & 446 & 6 & 15 & 28 & 14 & 29 & 91 & 71 & 66 & 34 & 21 & 31 & 40 \\
\hline $\begin{array}{l}\text { N Commitments } \\
\text { Assessed }\end{array}$ & 29 & 1 & 1 & 1 & 3 & 3 & 3 & 3 & 3 & 3 & 2 & 5 & 1 \\
\hline Overall Compliance & $80 \%$ & $88 \%$ & $68 \%$ & $85 \%$ & $88 \%$ & $85 \%$ & $72 \%$ & $79 \%$ & $80 \%$ & $71 \%$ & $85 \%$ & $76 \%$ \\
0.6 & 0.75 & 0.35 & 0.7 & 0.75 & 0.7 & 0.44 & 0.58 & 0.6 & 0.41 & 0.7 & 0.52 & 0.80 \\
\hline N of Ministerial & 40 & 2 & 1 & 2 & 3 & 3 & 6 & 3 & 6 & 5 & 4 & 4 & 1 \\
Meetings & & & & & & & & & & & & \\
\hline
\end{tabular}




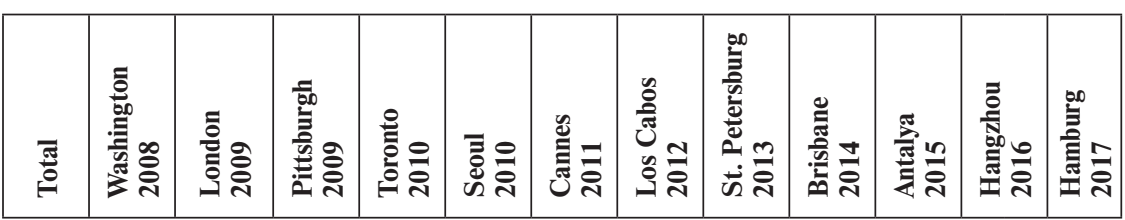

Financial Regulation

\begin{tabular}{|l|c|c|c|c|c|c|c|c|c|c|c|c|c|}
\hline N Commitments & 318 & 59 & 45 & 23 & 12 & 24 & 38 & 18 & 20 & 7 & 8 & 25 & 39 \\
\hline N Commitments & 28 & 3 & 1 & 2 & 1 & 4 & 3 & 3 & 1 & 1 & 1 & 5 & 3 \\
Assessed & & & & & & & & & & & & \\
\hline Overall Compliance & $76 \%$ & $77 \%$ & $48 \%$ & $74 \%$ & $55 \%$ & $81 \%$ & $86 \%$ & $68 \%$ & $68 \%$ & $85 \%$ & $92 \%$ & $85 \%$ \\
0.52 & 0.54 & -0.05 & 0.47 & 0.1 & 0.61 & 0.71 & 0.36 & 0.35 & 0.7 & 0.84 & 0.7 \\
& 0.998 \\
\hline N of Ministerial & 40 & 2 & 1 & 2 & 3 & 3 & 6 & 3 & 6 & 5 & 4 & 4 & 1 \\
Meetings & & & & & & & & & & & & \\
\hline
\end{tabular}

Trade

\begin{tabular}{|l|c|c|c|c|c|c|c|c|c|c|c|c|c|}
\hline N Commitments & 164 & 5 & 14 & 6 & 9 & 17 & 15 & 10 & 12 & 9 & 14 & 24 & 29 \\
\hline $\begin{array}{l}\text { N Commitments } \\
\text { Assessed }\end{array}$ & 19 & 3 & 1 & 1 & 1 & 1 & 1 & 2 & 1 & 1 & 3 & 3 & 1 \\
\hline Overall Compliance & $63 \%$ & $64 \%$ & $75 \%$ & $53 \%$ & $58 \%$ & $25 \%$ & $63 \%$ & $80 \%$ & $33 \%$ & $63 \%$ & $80 \%$ & $79 \%$ & $78 \%$ \\
& 0.26 & 0.27 & 0.5 & 0.05 & 0.15 & -0.5 & 0.25 & 0.6 & -0.35 & 0.25 & 0.6 & 0.57 & 0.55 \\
\hline $\begin{array}{l}\text { Nof Ministerial } \\
\text { Meetings }\end{array}$ & 4 & 0 & 0 & 0 & 0 & 0 & 0 & 1 & 0 & 1 & 1 & 1 & 0 \\
\hline
\end{tabular}




\section{Appendix C-1 \\ Overall Compliance by Catalysts in Commitments}

\begin{tabular}{|c|c|c|c|c|c|}
\hline Catalyst & Value & Count & Compliance & Difference & Significance \\
\hline \multirow[t]{2}{*}{ Priority Placement } & 0 & 233 & 0.438 & & \\
\hline & 1 & 10 & 0.435 & +0.003 & No \\
\hline \multirow[t]{2}{*}{ Past Reference to Summit } & 0 & 224 & 0.438 & & \\
\hline & 1 & 19 & 0.439 & +0.001 & No \\
\hline \multirow[t]{2}{*}{ Remit } & 0 & 236 & 0.443 & & \\
\hline & 1 & 7 & 0.271 & -0.171 & No \\
\hline \multirow[t]{2}{*}{ Target } & 0 & 218 & 0.447 & & \\
\hline & 1 & 25 & 0.354 & -0.093 & No \\
\hline \multirow[t]{2}{*}{ One-Year Time Table } & 0 & 221 & 0.445 & & \\
\hline & 1 & 22 & 0.367 & -0.078 & No \\
\hline \multirow[t]{2}{*}{ Multi-Year Time Table } & 0 & 209 & 0.457 & & \\
\hline & 1 & 34 & 0.317 & -0.140 & $5 \%$ \\
\hline \multirow[t]{2}{*}{ Self-Monitoring } & 0 & 237 & 0.447 & & \\
\hline & 1 & 6 & 0.067 & -0.380 & $1 \%$ \\
\hline \multirow[t]{2}{*}{ Money Mobilized } & 0 & 232 & 0.445 & & \\
\hline & 1 & 11 & 0.275 & -0.170 & No \\
\hline \multirow[t]{2}{*}{ Specified Agent } & 0 & 217 & 0.449 & & \\
\hline & 1 & 26 & 0.346 & -0.103 & No \\
\hline \multirow[t]{2}{*}{ Institutional Body } & 0 & 239 & 0.442 & & \\
\hline & 1 & 3 & 0.217 & -0.226 & No \\
\hline \multirow{2}{*}{ Core International Organization } & 0 & 229 & 0.436 & & \\
\hline & 1 & 14 & 0.468 & +0.032 & No \\
\hline \multirow{2}{*}{$\begin{array}{l}\text { Other International } \\
\text { Organization }\end{array}$} & 0 & 236 & 0.448 & & \\
\hline & 1 & 7 & 0.085 & -0.363 & $1 \%$ \\
\hline \multirow[t]{2}{*}{ Regional Organization } & 0 & 241 & 0.441 & & \\
\hline & 1 & 2 & 0 & -0.441 & $5 \%$ \\
\hline \multirow[t]{2}{*}{ International Law } & 0 & 225 & 0.445 & & \\
\hline & 1 & 18 & 0.336 & -0.108 & No \\
\hline \multirow[t]{2}{*}{ Ministers } & 0 & 239 & 0.432 & & \\
\hline & 1 & 4 & 0.757 & +0.325 & $5 \%$ \\
\hline \multirow[t]{2}{*}{ Civil Society } & 0 & 240 & 0.440 & & \\
\hline & 1 & 3 & 0.233 & -0.203 & No \\
\hline \multirow[t]{2}{*}{ Private Sector } & 0 & 231 & 0.440 & & \\
\hline & 1 & 12 & 0.377 & -0.064 & No \\
\hline \multirow[t]{2}{*}{ Country or Region } & 0 & 239 & 0.444 & & \\
\hline & 1 & 4 & 0.063 & -0.381 & $5 \%$ \\
\hline
\end{tabular}

Note. Catalysts Past Reference to Ministerial, International Organization Accountability Request, Surveillance, International Organizations Surveillance are not included in any of the 243 commitments assessed for compliance. 


\section{Appendix C-2 \\ Overall Compliance by Number of Catalysts in Commitment}

\begin{tabular}{|c|c|c|}
\hline $\begin{array}{c}\text { Number of Catalysts } \\
\text { in Commitment }\end{array}$ & N of Commitments & $\begin{array}{c}\text { Average Compliance With Commitments } \\
\text { With N Catalysts }\end{array}$ \\
\hline 0 & 108 & $77 \%(0.53)$ \\
\hline 1 & 76 & $69 \%(0.39)$ \\
\hline 2 & 41 & $68 \%(0.36)$ \\
\hline 3 & 9 & $66 \%(0.32)$ \\
\hline 4 & 5 & $64 \%(0.28)$ \\
\hline 5 & 2 & $69 \%(0.38)$ \\
\hline 6 & 2 & $50 \%(0.00)$ \\
\hline
\end{tabular}

\section{Appendix D \\ Catalysts Effect on Compliance}

OLS Regression Results

Standard errors in parentheses

\begin{tabular}{|l|c|c|}
\hline \multicolumn{1}{|c|}{ Variables } & $\mathbf{( 1 )}$ & (2) \\
\cline { 2 - 3 } & Average compliance & Average compliance \\
\hline MYTT & & $-0.141^{* *}$ \\
\hline & $-0.159^{* *}$ & $(0.0677)$ \\
\hline Self-monitoring & $(0.0693)$ & $-0.457^{* * *}$ \\
\hline & $-0.414^{* * *}$ & $(0.149)$ \\
\hline Other international organization & $(0.152)$ & $-0.362^{* *}$ \\
\hline & $-0.439^{* * *}$ & $(0.141)$ \\
\hline Ministers & $(0.143)$ & $0.423^{* *}$ \\
\hline & $0.466^{* *}$ & $(0.185)$ \\
\hline Country or region & $(0.190)$ & -0.275 \\
\hline & $-0.339^{*}$ & $(0.183)$ \\
\hline Pre-summit ministerial meeting & $(0.187)$ & $0.175^{* * *}$ \\
\hline & & $(0.0481)$ \\
\hline Constant & & $0.408^{* * *}$ \\
\hline
\end{tabular}

$$
* * * p<0.01, * * p<0.05, * p<0.1 \text {. }
$$




\section{Appendix E}

Compliance Catalysts by Country

\begin{tabular}{|c|c|c|c|c|}
\hline \multirow[t]{2}{*}{ Country } & \multirow[t]{2}{*}{ Catalysts } & \multicolumn{2}{|c|}{ Probability of Full Compliance } & \multirow[b]{2}{*}{ Difference, $\%$} \\
\hline & & No Catalyst, $\%$ & With Catalyst & \\
\hline Argentina $\mathrm{N}=231$ & Target $(-)$ & 43 & 15 & -28 \\
\hline \multicolumn{5}{|l|}{ Australia $\mathrm{N}=236$} \\
\hline Brazil N $=229$ & Ministers (+) & 52 & 99 & +47 \\
\hline Canada $\mathrm{N}=235$ & Specified Agent (-) & 75 & 53 & -22 \\
\hline \multicolumn{5}{|l|}{ China $\mathrm{N}=231$} \\
\hline \multicolumn{5}{|l|}{ France $\mathrm{N}=236$} \\
\hline \multirow{3}{*}{$\begin{array}{l}\text { Germany } \\
\mathrm{N}=233\end{array}$} & MYTT (-) & 76 & 55 & -21 \\
\hline & Self-Monitoring (-) & 74 & 28 & -46 \\
\hline & Other IO (-) & 74 & 38 & -36 \\
\hline \multirow{4}{*}{$\begin{array}{l}\text { India } \\
\mathrm{N}=233\end{array}$} & MYTT (-) & 55 & 33 & -22 \\
\hline & Money Mobilized (-) & 54 & 15 & -39 \\
\hline & Specified Agent (-) & 54 & 32 & -22 \\
\hline & International Law (-) & 54 & 27 & -27 \\
\hline \multicolumn{5}{|l|}{ Indonesia $\mathrm{N}=231$} \\
\hline Italy $\mathrm{N}=233$ & $\begin{array}{l}\text { Target (+) } \\
\text { MYTT (-) }\end{array}$ & $\begin{array}{l}48 \\
51\end{array}$ & $\begin{array}{l}63 \\
43\end{array}$ & $\begin{array}{l}+15 \\
-8\end{array}$ \\
\hline \multicolumn{5}{|l|}{ Japan $\mathrm{N}=235$} \\
\hline \multicolumn{5}{|l|}{ Korea $\mathrm{N}=235$} \\
\hline Mexico $N=234$ & Private Sector $(-)$ & 48 & 15 & -33 \\
\hline \multicolumn{5}{|l|}{ Russia $N=234$} \\
\hline Saudi Arabia N = 229 & Specified Agent (-) & 35 & 19 & -16 \\
\hline \multicolumn{5}{|l|}{ South Africa $N=231$} \\
\hline Turkey $\mathrm{N}=228$ & MYTT (-) & 41 & 16 & -25 \\
\hline \multirow[t]{2}{*}{$\mathrm{UK} N=236$} & Target $(-)$ & 76 & 60 & -16 \\
\hline & Self-Monitoring (-) & 76 & 39 & -37 \\
\hline USA N $=237$ & MYTT (-) & 63 & 37 & -26 \\
\hline \multirow[t]{2}{*}{$E U N=228$} & 1YTT (-) & 76 & 53 & -23 \\
\hline & MYTT (-) & 76 & 63 & -13 \\
\hline
\end{tabular}




\begin{tabular}{|c|c|c|c|c|c|c|c|c|c|c|c|c|c|c|c|c|c|c|c|c|c|c|c|}
\hline & త્త్ & & & & & & & & & & & & & & & & & & & & & & ¿ \\
\hline & $\stackrel{\vartheta}{\vartheta}$ & & & & & & & & & & & & & & & & & & & & & 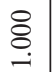 & $\stackrel{\text { ff }}{m}$ \\
\hline & $\stackrel{\mathscr{Q}}{=}$ & & & & & & & & & & & & & & & & & & & & $\underset{-}{\stackrel{-}{0}}$ & 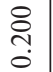 & 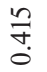 \\
\hline & $E$ & & & & & & & & & & & & & & & & & & & 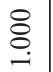 & $\begin{array}{l}\stackrel{9}{\subseteq} \\
0\end{array}$ & 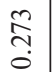 & $\stackrel{\vec{m}}{0}$ \\
\hline & $\stackrel{6}{=}$ & & & & & & & & & & & & & & & & & & $\stackrel{8}{.}$ & ते & 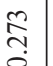 & $\underset{\sim}{\stackrel{\sim}{2}}$ & ڤે \\
\hline & $\stackrel{6}{=}$ & & & & & & & & & & & & & & & & & 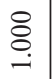 & $\frac{0}{m}$ & 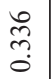 & 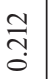 & 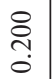 & 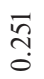 \\
\hline & $\widehat{\Theta}$ & & & & & & & & & & & & & & & & $\underset{-}{\stackrel{一}{\circ}}$ & 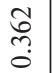 & 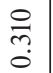 & $\begin{array}{l}\begin{array}{l}0 \\
0 \\
0 \\
0\end{array}\end{array}$ & $\frac{8}{0}$ & $\begin{array}{c}\frac{n}{m} \\
\stackrel{0}{0}\end{array}$ & 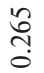 \\
\hline & $\stackrel{\overparen{m}}{=}$ & & & & & & & & & & & & & & & 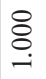 & ڤे & 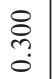 & 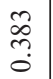 & $\begin{array}{l}\stackrel{\partial}{+} \\
\dot{0}\end{array}$ & $\frac{\widetilde{\sigma}}{0}$ & $\begin{array}{l}\text { ț } \\
\text { N̦ } \\
0\end{array}$ & ڤ్రి \\
\hline & $\widehat{\Xi}$ & & & & & & & & & & & & & & $\underset{-}{\stackrel{\circ}{\circ}}$ & ָे & \begin{tabular}{l}
$\infty$ \\
\multirow{2}{0}{} \\
0
\end{tabular} & $\mid \begin{array}{l}n \\
0 \\
0 \\
0\end{array}$ & $\frac{\hat{\sigma}}{0}$ & $\begin{array}{l}\tilde{n} \\
\tilde{0}\end{array}$ & $\begin{array}{l}\tilde{\Xi} \\
\tilde{3} \\
\tilde{0}\end{array}$ & \begin{tabular}{l}
$\tilde{I}$ \\
\multirow{0}{0}{}
\end{tabular} & $\stackrel{\text { Iิ }}{\stackrel{2}{0}}$ \\
\hline & $\widehat{\Xi}$ & & & & & & & & & & & & & 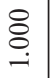 & $\begin{array}{l}\tilde{w} \\
\tilde{c} \\
0\end{array}$ & 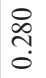 & $\begin{array}{l}\text { त̂ } \\
\text { ָे }\end{array}$ & 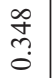 & $\stackrel{\widehat{\vartheta}}{0}$ & 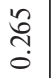 & $\begin{array}{c}\overline{0} \\
0 \\
0\end{array}$ & 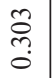 & ले \\
\hline & $\stackrel{\varrho}{\varrho}$ & & & & & & & & & & & & 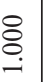 & $\begin{array}{c}\vec{f} \\
\stackrel{m}{0}\end{array}$ & 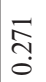 & f) & $\begin{array}{l}\text { ते } \\
\text { ֻे }\end{array}$ & 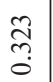 & 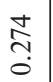 & $\begin{array}{l}\tilde{I} \\
\stackrel{+}{0} \\
\stackrel{0}{0}\end{array}$ & 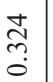 & $\begin{array}{c}\tilde{n} \\
\stackrel{\tilde{c}}{0} \\
0\end{array}$ & 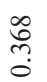 \\
\hline & $\hat{\sigma}$ & & & & & & & & & & & . & 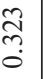 & $\begin{array}{l}\hat{6} \\
0 \\
0\end{array}$ & 苞 & ‡. & $\stackrel{m}{\tilde{m}}$ & $\underset{\hat{\jmath}}{\tilde{0}}$ & 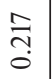 & ๙ิ) & $\frac{n}{\tilde{n}}$ & $\underset{0}{\cong}$ & $\stackrel{\partial}{\stackrel{0}{0}}$ \\
\hline$\frac{4}{6}$ & (2) & & & & & & & & & $\stackrel{8}{\circ}$ & j & 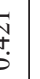 & 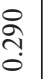 & ڤે & 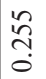 & ले & ले & \begin{tabular}{l}
$\overrightarrow{\tilde{n}}$ \\
\multirow{2}{0}{}
\end{tabular} & \begin{tabular}{l} 
กิ \\
\multirow{2}{0}{}
\end{tabular} & 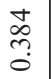 & $\begin{array}{l}\text { ț } \\
\stackrel{0}{\circ} \\
0\end{array}$ & సે & ஸ़ \\
\hline & $E$ & & & & & & & & $\stackrel{\text { }}{.}$ & స్ & is & C. & 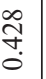 & 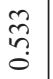 & \begin{tabular}{l}
\multirow{2}{0}{} \\
లై
\end{tabular} & 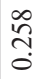 & Әे & \begin{tabular}{l}
$\hat{s}$ \\
\multirow{2}{0}{} \\
0
\end{tabular} & $\underset{\tilde{\vartheta}}{\tilde{\sigma}}$ & $\begin{array}{c}\tilde{\approx} \\
\tilde{0}\end{array}$ & $\begin{array}{c}\stackrel{P}{\Im} \\
\stackrel{5}{\circ}\end{array}$ & 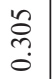 & 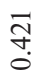 \\
\hline 5 & $\Theta$ & & & & & & & $\stackrel{8}{\circ}$ & $\begin{array}{l}\stackrel{n}{\infty} \\
\stackrel{\infty}{+} \\
\dot{0}\end{array}$ & $\stackrel{8}{8}$ & گે & ज़ & 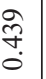 & $\underset{\tilde{n}}{\tilde{m}}$ & ஸ̂. & ڤ̊ & 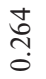 & $\begin{array}{l}\stackrel{+}{\circ} \\
\text { స్ } \\
0\end{array}$ & 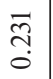 & \begin{tabular}{l}
$\infty$ \\
\multirow{2}{\jmath}{} \\
0
\end{tabular} & $\begin{array}{l}\infty \\
\stackrel{0}{*} \\
0\end{array}$ & 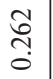 & 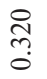 \\
\hline 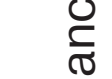 & $\sqrt{6}$ & & & & & & \begin{tabular}{l} 
\\
\hdashline \\
\hdashline \\
\end{tabular} & ָ̊ & $\begin{array}{l}\tilde{N} \\
\text { ஸे } \\
0\end{array}$ & 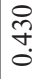 & वे & $\frac{6}{6}$ & 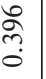 & 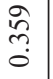 & ¿̊. & $\begin{array}{l}\bar{n} \\
\tilde{0} \\
0\end{array}$ & 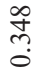 & $\begin{array}{l}\stackrel{8}{0} \\
\stackrel{1}{0} \\
0\end{array}$ & 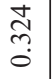 & $\begin{array}{l}\stackrel{0}{0} \\
\stackrel{0}{0} \\
0\end{array}$ & 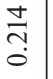 & 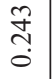 & बें \\
\hline & $\widehat{\Theta}$ & & & & 8 & & $\begin{array}{c}+ \\
\stackrel{t}{3} \\
0\end{array}$ & సิ & 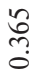 & $\stackrel{0}{\sim}$ & ఏ & y. & 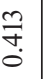 & \begin{tabular}{l} 
İ \\
\multirow{0}{0}{}
\end{tabular} & $\stackrel{\infty}{\stackrel{\infty}{0}}$ & 吕 & \begin{tabular}{l}
$\stackrel{0}{0}$ \\
\multirow{2}{0}{} \\
0
\end{tabular} & $\begin{array}{c}\vec{F} \\
\tilde{m} \\
0\end{array}$ & 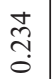 & $\frac{\vec{m}}{\hat{0}}$ & $\begin{array}{c}\vec{m} \\
\stackrel{0}{0}\end{array}$ & $\begin{array}{c}\stackrel{2}{0} \\
\text { है }\end{array}$ & $\begin{array}{l}\tilde{y} \\
\stackrel{y}{0} \\
0\end{array}$ \\
\hline & (이 & & & ه̊ & ơ & & 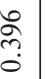 & $\frac{\text { gे }}{0}$ & 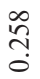 & $\begin{array}{l}8 \\
\stackrel{0}{\circ} \\
\end{array}$ & 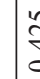 & $\begin{array}{l}\text { a } \\
\text { t. }\end{array}$ & 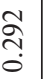 & $\begin{array}{c}0 \\
\text { m. } \\
0\end{array}$ & 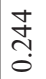 & ले & 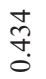 & 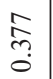 & 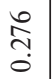 & $\begin{array}{l}\overrightarrow{\mathcal{T}} \\
\stackrel{0}{\circ}\end{array}$ & $\frac{F}{\dot{\theta}}$ & $\begin{array}{c}\infty \\
\infty \\
0\end{array}$ & $\begin{array}{l}n \\
\tilde{n} \\
\tilde{n} \\
0\end{array}$ \\
\hline$\stackrel{\oplus}{ \pm}$ & (ิ) & & هి & ڤે & $\stackrel{\infty}{m}$ & & 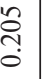 & $\begin{array}{l}\vec{\sim} \\
\stackrel{\leftrightarrow}{0}\end{array}$ & 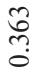 & $\underset{\widetilde{N}}{\widetilde{N}}$ & d & بـ & $\overline{\vec{\Upsilon}}$ & 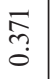 & $\begin{array}{l}n \\
\tilde{n} \\
\tilde{n} \\
0\end{array}$ & $\frac{\infty}{\tilde{c}}$ & \begin{tabular}{l}
$\hat{\infty}$ \\
\multirow{2}{N}{} \\
0
\end{tabular} & 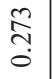 & ثે & 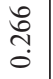 & $\begin{array}{c}\tilde{N} \\
\vdots \\
0\end{array}$ & $\begin{array}{l}\stackrel{a}{\stackrel{J}{2}} \\
\text { Oे }\end{array}$ & 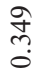 \\
\hline$\circlearrowleft$ & 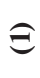 & $\underset{-}{\stackrel{-}{\circ}}$ & $\begin{array}{l}\text { कै } \\
\text { ֻै }\end{array}$ & $\stackrel{\infty}{+\infty}$ & fo & & $\begin{array}{c}\infty \\
\infty \\
0 \\
0 \\
0\end{array}$ & ڤે & $\frac{3}{0}$ & $\stackrel{q}{F}$ & \& & 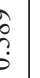 & 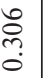 & $\frac{n}{0}$ & $\stackrel{0}{m}$ & 吕 & 号 & $\begin{array}{l}\frac{\infty}{m} \\
\stackrel{0}{0}\end{array}$ & 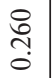 & 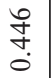 & $\frac{n}{0}$ & ટ્సે & 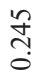 \\
\hline 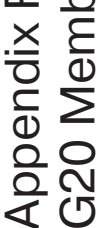 & 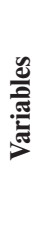 & 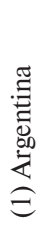 & 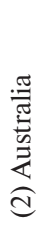 & 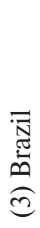 & త్ర & & 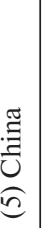 & 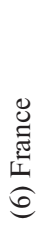 & 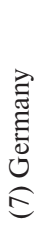 & $\frac{\tilde{g}}{\underline{\sigma}}$ & 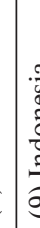 & 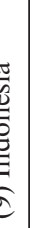 & $\begin{array}{l}\frac{\lambda}{\underline{E}} \\
\stackrel{\vec{\Theta}}{\Theta}\end{array}$ & 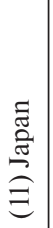 & 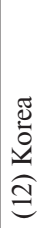 & 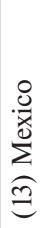 & 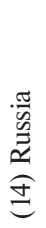 & 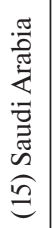 & 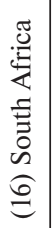 & 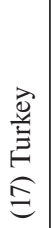 & $\begin{array}{l}\stackrel{y}{J} \\
\stackrel{\alpha}{=}\end{array}$ & $\begin{array}{l}\overleftrightarrow{2} \\
2 \\
\stackrel{2}{\Xi}\end{array}$ & 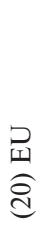 \\
\hline
\end{tabular}




\section{Appendix G}

G2 Hypothesis. Ordinal Logistic Model

\begin{tabular}{|c|c|c|c|c|c|c|}
\hline \multirow[t]{2}{*}{ Variables } & (1) & (2) & (3) & (4) & (5) & (6) \\
\hline & Argentina & Australia & Brazil & Canada & France & Germany \\
\hline \multirow[t]{2}{*}{ China } & 0.339 & -0.481 & -0.0787 & $1.465^{* *}$ & 0.411 & 0.210 \\
\hline & $(0.556)$ & $(0.595)$ & $(0.566)$ & $(0.731)$ & $(0.597)$ & $(0.654)$ \\
\hline \multirow[t]{2}{*}{ USA } & -0.137 & 0.282 & 0.222 & $1.573^{* * *}$ & 0.452 & 0.450 \\
\hline & $(0.469)$ & $(0.518)$ & $(0.467)$ & $(0.556)$ & $(0.519)$ & $(0.552)$ \\
\hline \multirow[t]{2}{*}{ USA x China } & -0.106 & 0.399 & 0.151 & -1.014 & 0.201 & 0.730 \\
\hline & $(0.656)$ & $(0.760)$ & $(0.684)$ & $(0.944)$ & $(0.769)$ & $(0.928)$ \\
\hline \multirow[t]{2}{*}{ Australia } & 0.338 & & -0.427 & $0.775^{* *}$ & -0.408 & 0.457 \\
\hline & $(0.325)$ & & $(0.337)$ & $(0.365)$ & $(0.386)$ & $(0.387)$ \\
\hline \multirow[t]{2}{*}{ Brazil } & $0.762 * * *$ & -0.378 & & -0.356 & $-0.517^{*}$ & 0.248 \\
\hline & $(0.249)$ & $(0.296)$ & & $(0.342)$ & $(0.314)$ & $(0.332)$ \\
\hline \multirow[t]{2}{*}{ Canada } & $1.459 * * *$ & 0.438 & -0.497 & & -0.0522 & -0.223 \\
\hline & $(0.355)$ & $(0.381)$ & $(0.351)$ & & $(0.381)$ & $(0.426)$ \\
\hline \multirow[t]{2}{*}{ France } & 0.151 & -0.334 & -0.486 & 0.0974 & & $1.075^{* * *}$ \\
\hline & $(0.340)$ & $(0.365)$ & $(0.352)$ & $(0.404)$ & & $(0.401)$ \\
\hline \multirow[t]{2}{*}{ Germany } & -0.465 & 0.503 & 0.129 & -0.218 & $1.052^{* * *}$ & \\
\hline & $(0.361)$ & $(0.365)$ & $(0.349)$ & $(0.392)$ & $(0.367)$ & \\
\hline \multirow[t]{2}{*}{ India } & $0.455^{*}$ & 0.155 & $0.486^{*}$ & -0.260 & -0.334 & 0.247 \\
\hline & $(0.276)$ & $(0.304)$ & $(0.278)$ & $(0.348)$ & $(0.315)$ & $(0.351)$ \\
\hline \multirow[t]{2}{*}{ Indonesia } & 0.204 & $0.480^{*}$ & $0.644^{* *}$ & -0.393 & 0.291 & -0.366 \\
\hline & $(0.248)$ & $(0.290)$ & $(0.262)$ & $(0.342)$ & $(0.294)$ & $(0.344)$ \\
\hline \multirow[t]{2}{*}{ Italy } & -0.137 & 0.000393 & -0.0767 & $0.704^{* *}$ & $0.671^{* *}$ & 0.470 \\
\hline & $(0.280)$ & $(0.305)$ & $(0.275)$ & $(0.339)$ & $(0.303)$ & $(0.334)$ \\
\hline \multirow[t]{2}{*}{ Japan } & $-0.636^{* *}$ & 0.411 & $0.663^{* *}$ & $0.963^{* * *}$ & 0.344 & $1.113^{* * *}$ \\
\hline & $(0.288)$ & $(0.315)$ & $(0.293)$ & $(0.340)$ & $(0.326)$ & $(0.330)$ \\
\hline \multirow[t]{2}{*}{ Korea } & 0.367 & $0.585^{* *}$ & -0.184 & $-0.875^{* *}$ & $0.515^{*}$ & 0.0263 \\
\hline & $(0.278)$ & $(0.297)$ & $(0.274)$ & $(0.363)$ & $(0.306)$ & $(0.343)$ \\
\hline \multirow[t]{2}{*}{ Mexico } & 0.359 & 0.438 & 0.163 & -0.402 & 0.263 & -0.461 \\
\hline & $(0.263)$ & $(0.305)$ & $(0.265)$ & $(0.356)$ & $(0.313)$ & $(0.358)$ \\
\hline \multirow[t]{2}{*}{ Russia } & $0.576^{* *}$ & 0.0911 & 0.264 & -0.00466 & 0.187 & 0.310 \\
\hline & $(0.241)$ & $(0.281)$ & $(0.253)$ & $(0.314)$ & $(0.290)$ & $(0.324)$ \\
\hline \multirow[t]{2}{*}{ Saudi Arabia } & 0.0465 & 0.0616 & $0.557^{* *}$ & $0.693^{* *}$ & -0.101 & 0.135 \\
\hline & $(0.236)$ & $(0.282)$ & $(0.248)$ & $(0.326)$ & $(0.287)$ & $(0.329)$ \\
\hline \multirow[t]{2}{*}{ South Africa } & -0.0555 & -0.0567 & 0.147 & -0.176 & 0.0743 & 0.00368 \\
\hline & $(0.246)$ & $(0.276)$ & $(0.254)$ & $(0.332)$ & $(0.284)$ & $(0.341)$ \\
\hline \multirow[t]{2}{*}{ Turkey } & 0.415 & -0.0694 & 0.396 & 0.335 & 0.00173 & 0.430 \\
\hline & $(0.253)$ & $(0.300)$ & $(0.263)$ & $(0.352)$ & $(0.305)$ & $(0.341)$ \\
\hline \multirow[t]{2}{*}{ UK } & 0.00526 & $0.665^{*}$ & -0.164 & 0.209 & $0.723^{* *}$ & 0.629 \\
\hline & $(0.329)$ & $(0.355)$ & $(0.360)$ & $(0.423)$ & $(0.367)$ & $(0.396)$ \\
\hline EU & -0.289 & 0.339 & $0.824^{* *}$ & $0.750^{* *}$ & 0.0938 & 0.414 \\
\hline
\end{tabular}




\begin{tabular}{|l|c|c|c|c|c|c|}
\hline \multirow{2}{*}{ Variables } & $\mathbf{( 1 )}$ & $\mathbf{( 2 )}$ & $\mathbf{( 3 )}$ & $\mathbf{( 4 )}$ & $\mathbf{( 5 )}$ & $\mathbf{( 6 )}$ \\
\cline { 2 - 7 } & Argentina & Australia & Brazil & Canada & France & Germany \\
\hline & $(0.310)$ & $(0.343)$ & $(0.329)$ & $(0.356)$ & $(0.358)$ & $(0.362)$ \\
\hline Argentina & & 0.326 & $0.845^{* * *}$ & $1.286^{* * *}$ & 0.189 & -0.387 \\
\hline & & $(0.295)$ & $(0.262)$ & $(0.339)$ & $(0.307)$ & $(0.360)$ \\
\hline Constant cut 1 & -0.376 & $-2.465^{* * *}$ & $-1.693^{* * *}$ & $-2.308^{* * *}$ & $-2.423^{* * *}$ & $-1.852^{* * *}$ \\
\hline & $(0.351)$ & $(0.466)$ & $(0.368)$ & $(0.479)$ & $(0.504)$ & $(0.461)$ \\
\hline Constant cut 2 & $2.174^{* * *}$ & $0.832^{* *}$ & $0.611^{*}$ & $0.821^{* *}$ & $1.122^{* * *}$ & $1.229^{* * *}$ \\
\hline & $(0.398)$ & $(0.382)$ & $(0.351)$ & $(0.392)$ & $(0.406)$ & $(0.411)$ \\
\hline & & & & & & 211 \\
\hline Observations & 211 & 211 & 211 & 211 & & 211 \\
\hline
\end{tabular}

Note. Standard errors in parentheses.

*** $p<0.01,{ }^{* *} p<0.05, * p<0.1$.

\begin{tabular}{|c|c|c|c|c|c|c|}
\hline \multirow[t]{2}{*}{ Variables } & (7) & (8) & (9) & (10) & (11) & (12) \\
\hline & India & Indonesia & Italy & Japan & Korea & Mexico \\
\hline \multirow{2}{*}{ China } & $1.109^{* *}$ & $1.008^{*}$ & -0.0221 & 0.100 & 0.253 & 0.437 \\
\hline & $(0.553)$ & $(0.560)$ & $(0.550)$ & $(0.569)$ & $(0.569)$ & $(0.538)$ \\
\hline \multirow[t]{2}{*}{ USA } & $0.803^{*}$ & -0.0355 & -0.133 & -0.330 & 0.563 & 0.289 \\
\hline & $(0.461)$ & $(0.443)$ & $(0.468)$ & $(0.493)$ & $(0.479)$ & $(0.452)$ \\
\hline \multirow[t]{2}{*}{ USA x China } & 0.312 & -0.705 & $1.166^{*}$ & 0.961 & -0.101 & -0.0389 \\
\hline & $(0.678)$ & $(0.660)$ & $(0.668)$ & $(0.708)$ & $(0.695)$ & $(0.651)$ \\
\hline \multirow[t]{2}{*}{ Argentina } & $0.490^{*}$ & 0.148 & -0.114 & $-0.753^{* *}$ & $0.544^{* *}$ & 0.334 \\
\hline & $(0.260)$ & $(0.249)$ & $(0.267)$ & $(0.293)$ & $(0.267)$ & $(0.256)$ \\
\hline \multirow[t]{2}{*}{ Australia } & 0.0336 & 0.288 & -0.134 & $0.652^{* *}$ & $0.760^{* *}$ & 0.469 \\
\hline & $(0.331)$ & $(0.332)$ & $(0.330)$ & $(0.324)$ & $(0.322)$ & $(0.317)$ \\
\hline \multirow[t]{2}{*}{ Brazil } & $0.456^{*}$ & $0.627 * *$ & -0.0794 & $0.671^{* *}$ & -0.210 & 0.234 \\
\hline & $(0.259)$ & $(0.246)$ & $(0.261)$ & $(0.268)$ & $(0.274)$ & $(0.250)$ \\
\hline \multirow[t]{2}{*}{ Canada } & -0.419 & -0.438 & $0.822 * *$ & $0.986^{* * *}$ & $-0.981^{* * *}$ & -0.440 \\
\hline & $(0.362)$ & $(0.347)$ & $(0.356)$ & $(0.374)$ & $(0.374)$ & $(0.339)$ \\
\hline \multirow[t]{2}{*}{ France } & -0.228 & 0.220 & $0.646^{*}$ & 0.446 & $0.698^{* *}$ & 0.341 \\
\hline & $(0.347)$ & $(0.320)$ & $(0.338)$ & $(0.352)$ & $(0.328)$ & $(0.324)$ \\
\hline \multirow[t]{2}{*}{ Germany } & 0.176 & -0.370 & 0.486 & $1.211^{* * *}$ & -0.0142 & -0.254 \\
\hline & $(0.362)$ & $(0.342)$ & $(0.340)$ & $(0.342)$ & $(0.341)$ & $(0.340)$ \\
\hline \multirow[t]{2}{*}{ Indonesia } & $0.569^{* *}$ & & $0.434^{*}$ & -0.195 & $0.541^{* *}$ & $0.411^{*}$ \\
\hline & $(0.258)$ & & $(0.252)$ & $(0.279)$ & $(0.261)$ & $(0.241)$ \\
\hline \multirow[t]{2}{*}{ Italy } & -0.0796 & 0.349 & & -0.0249 & -0.0863 & $0.618^{* *}$ \\
\hline & $(0.281)$ & $(0.264)$ & & $(0.293)$ & $(0.274)$ & $(0.266)$ \\
\hline \multirow[t]{2}{*}{ Japan } & -0.0571 & -0.244 & -0.187 & & $0.519^{*}$ & 0.182 \\
\hline & $(0.284)$ & $(0.284)$ & $(0.295)$ & & $(0.295)$ & $(0.276)$ \\
\hline Korea & 0.220 & 0.438 & -0.0675 & $0.647^{* *}$ & & 0.0749 \\
\hline
\end{tabular}




\begin{tabular}{|c|c|c|c|c|c|c|}
\hline \multirow[t]{3}{*}{ Variables } & (7) & (8) & (9) & (10) & (11) & (12) \\
\hline & India & Indonesia & Italy & Japan & Korea & Mexico \\
\hline & $(0.280)$ & $(0.274)$ & $(0.280)$ & $(0.286)$ & & $(0.279)$ \\
\hline \multirow[t]{2}{*}{ Mexico } & -0.0156 & $0.525^{* *}$ & $0.554^{* *}$ & 0.215 & -0.124 & \\
\hline & $(0.266)$ & $(0.244)$ & $(0.262)$ & $(0.282)$ & $(0.280)$ & \\
\hline \multirow[t]{2}{*}{ Russia } & 0.274 & 0.0886 & -0.145 & -0.225 & -0.122 & 0.272 \\
\hline & $(0.248)$ & $(0.238)$ & $(0.255)$ & $(0.276)$ & $(0.257)$ & $(0.246)$ \\
\hline \multirow[t]{2}{*}{ Saudi Arabia } & -0.0892 & 0.0783 & 0.321 & 0.382 & $0.768 * * *$ & -0.00229 \\
\hline & $(0.255)$ & $(0.233)$ & $(0.246)$ & $(0.257)$ & $(0.252)$ & $(0.240)$ \\
\hline \multirow[t]{2}{*}{ South Africa } & 0.152 & -0.115 & -0.0507 & 0.168 & -0.146 & $0.701^{* * *}$ \\
\hline & $(0.252)$ & $(0.228)$ & $(0.251)$ & $(0.262)$ & $(0.256)$ & $(0.236)$ \\
\hline \multirow[t]{2}{*}{ Turkey } & 0.258 & 0.331 & $0.490^{*}$ & -0.135 & 0.364 & 0.260 \\
\hline & $(0.258)$ & $(0.247)$ & $(0.257)$ & $(0.269)$ & $(0.267)$ & $(0.247)$ \\
\hline \multirow[t]{2}{*}{ UK } & $-0.715^{*}$ & 0.198 & 0.367 & -0.239 & $0.650^{*}$ & -0.310 \\
\hline & $(0.366)$ & $(0.322)$ & $(0.334)$ & $(0.370)$ & $(0.346)$ & $(0.328)$ \\
\hline \multirow[t]{2}{*}{ EU } & $0.610^{*}$ & -0.242 & 0.0909 & -0.160 & -0.290 & 0.173 \\
\hline & $(0.328)$ & $(0.329)$ & $(0.318)$ & $(0.341)$ & $(0.328)$ & $(0.307)$ \\
\hline \multirow[t]{2}{*}{ India } & & $0.596^{* *}$ & -0.0252 & -0.0192 & 0.173 & -0.0945 \\
\hline & & $(0.263)$ & $(0.277)$ & $(0.287)$ & $(0.288)$ & $(0.268)$ \\
\hline \multirow[t]{2}{*}{ Constant cut 1} & $-1.500^{* * *}$ & $-1.140^{* * *}$ & $-0.787^{* *}$ & -0.543 & $-1.893^{* * *}$ & $-1.247^{* * *}$ \\
\hline & $(0.370)$ & $(0.351)$ & $(0.356)$ & $(0.369)$ & $(0.381)$ & $(0.354)$ \\
\hline \multirow[t]{2}{*}{ Constant cut 2} & $1.408^{* * *}$ & $1.513^{* * *}$ & $2.096^{* * *}$ & $2.094^{* * *}$ & $0.864 * *$ & $1.479^{* * *}$ \\
\hline & $(0.372)$ & $(0.361)$ & $(0.396)$ & $(0.408)$ & $(0.357)$ & $(0.364)$ \\
\hline Observations & 211 & 211 & 211 & 211 & 211 & 211 \\
\hline
\end{tabular}

Note. Standard errors in parentheses.

*** $p<\mathrm{b} 0.01, * * p<0.05, * p<0.1$.

\begin{tabular}{|l|c|c|c|c|c|c|}
\hline \multirow{3}{*}{ Variables } & $\mathbf{( 1 3 )}$ & $\mathbf{( 1 4 )}$ & $\mathbf{( 1 5 )}$ & $\mathbf{( 1 6 )}$ & $\mathbf{( 1 7 )}$ & $\mathbf{( 1 8 )}$ \\
\cline { 2 - 7 } & Russia & Saudi Arabia & South Africa & Turkey & UK & EU \\
\hline & & & & & & \\
\hline China & -0.544 & -0.410 & 0.605 & -0.829 & 0.558 & 0.116 \\
\hline & $(0.530)$ & $(0.539)$ & $(0.518)$ & $(0.544)$ & $(0.712)$ & $(0.665)$ \\
\hline USA & 0.201 & -0.514 & 0.145 & -0.662 & -0.0144 & 0.0539 \\
\hline & $(0.444)$ & $(0.464)$ & $(0.452)$ & $(0.452)$ & $(0.563)$ & $(0.522)$ \\
\hline USA x China & $1.055^{*}$ & 0.274 & -0.528 & $1.121^{*}$ & -1.094 & 0.903 \\
\hline & $(0.635)$ & $(0.643)$ & $(0.618)$ & $(0.639)$ & $(0.844)$ & $(0.905)$ \\
\hline Argentina & $0.534^{* *}$ & -0.0152 & -0.0324 & $0.430^{*}$ & -0.196 & -0.314 \\
\hline & $(0.247)$ & $(0.245)$ & $(0.246)$ & $(0.251)$ & $(0.330)$ & $(0.327)$ \\
\hline Australia & 0.257 & 0.0370 & -0.0113 & -0.0412 & $0.866 * *$ & 0.386 \\
\hline & $(0.304)$ & $(0.308)$ & $(0.302)$ & $(0.307)$ & $(0.356)$ & $(0.385)$ \\
\hline
\end{tabular}




\begin{tabular}{|c|c|c|c|c|c|c|}
\hline \multirow[t]{2}{*}{ Variables } & (13) & (14) & (15) & (16) & (17) & (18) \\
\hline & Russia & Saudi Arabia & South Africa & Turkey & UK & $\mathbf{E U}$ \\
\hline \multirow[t]{2}{*}{ Brazil } & 0.384 & $0.533^{* *}$ & 0.0695 & 0.298 & 0.0479 & $0.949 * * *$ \\
\hline & $(0.254)$ & $(0.246)$ & $(0.243)$ & $(0.248)$ & $(0.333)$ & $(0.326)$ \\
\hline \multirow[t]{2}{*}{ Canada } & 0.0227 & $0.786^{* *}$ & -0.00298 & 0.386 & 0.273 & $0.918^{* *}$ \\
\hline & $(0.331)$ & $(0.342)$ & $(0.331)$ & $(0.338)$ & $(0.406)$ & $(0.382)$ \\
\hline \multirow[t]{2}{*}{ France } & 0.294 & -0.313 & 0.0422 & 0.0543 & $1.012 * * *$ & 0.185 \\
\hline & $(0.323)$ & $(0.345)$ & $(0.321)$ & $(0.327)$ & $(0.368)$ & $(0.381)$ \\
\hline \multirow[t]{2}{*}{ Germany } & 0.274 & 0.0134 & -0.0660 & 0.359 & 0.601 & 0.240 \\
\hline & $(0.330)$ & $(0.361)$ & $(0.335)$ & $(0.346)$ & $(0.373)$ & $(0.380)$ \\
\hline \multirow[t]{2}{*}{ India } & 0.299 & -0.192 & 0.168 & 0.205 & -0.497 & $0.633^{*}$ \\
\hline & $(0.265)$ & $(0.272)$ & $(0.269)$ & $(0.267)$ & $(0.338)$ & $(0.335)$ \\
\hline \multirow[t]{2}{*}{ Indonesia } & 0.141 & 0.0973 & -0.127 & 0.348 & 0.197 & -0.486 \\
\hline & $(0.240)$ & $(0.239)$ & $(0.235)$ & $(0.241)$ & $(0.313)$ & $(0.351)$ \\
\hline \multirow[t]{2}{*}{ Italy } & -0.103 & 0.276 & 0.0114 & $0.503^{*}$ & 0.454 & 0.426 \\
\hline & $(0.265)$ & $(0.263)$ & $(0.259)$ & $(0.263)$ & $(0.320)$ & $(0.333)$ \\
\hline \multirow[t]{2}{*}{ Japan } & -0.333 & 0.384 & 0.109 & 0.00571 & -0.0667 & 0.00408 \\
\hline & $(0.280)$ & $(0.265)$ & $(0.263)$ & $(0.271)$ & $(0.345)$ & $(0.335)$ \\
\hline \multirow[t]{2}{*}{ Korea } & -0.0562 & $0.749^{* * *}$ & -0.184 & 0.289 & 0.501 & -0.333 \\
\hline & $(0.266)$ & $(0.268)$ & $(0.261)$ & $(0.267)$ & $(0.331)$ & $(0.354)$ \\
\hline \multirow[t]{2}{*}{ Mexico } & 0.185 & 0.0776 & $0.680^{* * *}$ & 0.299 & -0.265 & 0.239 \\
\hline & $(0.255)$ & $(0.249)$ & $(0.245)$ & $(0.246)$ & $(0.343)$ & $(0.348)$ \\
\hline \multirow[t]{2}{*}{ Saudi Arabia } & $0.473^{* *}$ & & $0.480^{* *}$ & 0.0413 & -0.0311 & -0.202 \\
\hline & $(0.239)$ & & $(0.226)$ & $(0.236)$ & $(0.303)$ & $(0.318)$ \\
\hline \multirow[t]{2}{*}{ South Africa } & 0.249 & $0.540^{* *}$ & & 0.156 & 0.452 & 0.0983 \\
\hline & $(0.236)$ & $(0.228)$ & & $(0.237)$ & $(0.307)$ & $(0.312)$ \\
\hline \multirow[t]{2}{*}{ Turkey } & $0.513^{* *}$ & 0.0480 & 0.236 & & -0.213 & 0.223 \\
\hline & $(0.248)$ & $(0.247)$ & $(0.240)$ & & $(0.345)$ & $(0.329)$ \\
\hline \multirow[t]{2}{*}{ UK } & 0.102 & -0.115 & $0.582^{*}$ & -0.281 & & $1.184^{* * *}$ \\
\hline & $(0.321)$ & $(0.315)$ & $(0.313)$ & $(0.319)$ & & $(0.382)$ \\
\hline \multirow[t]{2}{*}{ EU } & -0.186 & -0.0151 & 0.0684 & 0.210 & $0.905^{* * *}$ & \\
\hline & $(0.304)$ & $(0.309)$ & $(0.294)$ & $(0.309)$ & $(0.349)$ & \\
\hline \multirow[t]{2}{*}{ Russia } & & $0.477^{* *}$ & 0.230 & $0.485^{* *}$ & -0.0156 & -0.358 \\
\hline & & $(0.240)$ & $(0.235)$ & $(0.242)$ & $(0.322)$ & $(0.321)$ \\
\hline \multirow[t]{2}{*}{ Constant cut 1} & $-1.029 * * *$ & $-0.673^{* *}$ & $-1.143^{* * *}$ & $-0.951^{* * *}$ & $-1.713^{* * *}$ & $-1.452^{* * *}$ \\
\hline & $(0.350)$ & $(0.342)$ & $(0.346)$ & $(0.349)$ & $(0.448)$ & $(0.425)$ \\
\hline \multirow[t]{2}{*}{ Constant cut 2} & $1.416^{* * *}$ & $1.873^{* * *}$ & $1.423^{* * *}$ & $1.794^{* * *}$ & $1.132 * * *$ & $1.176^{* * *}$ \\
\hline & $(0.361)$ & $(0.370)$ & $(0.352)$ & $(0.371)$ & $(0.396)$ & $(0.397)$ \\
\hline Observations & 211 & 211 & 211 & 211 & 211 & 211 \\
\hline
\end{tabular}

Note. Standard errors in parentheses.

$* * * p<0.01,{ }^{* *} p<0.05, * p<0.1$ 


\section{Appendix $\mathrm{H}$ \\ Compliance Correlations OLS Model}

\begin{tabular}{|l|c|}
\hline \multicolumn{1}{|c|}{ Variables } & (1) \\
\hline & Compliance Correlations \\
\hline GDP Correlations & 0.0204 \\
\hline Democracy & $(0.0188)$ \\
\hline & $-0.0320^{* *}$ \\
\hline BRICS & $(0.0126)$ \\
\hline & $0.0915^{* * *}$ \\
\hline EU & $(0.0199)$ \\
\hline & $0.0567^{* *}$ \\
\hline G7 & $(0.0237)$ \\
\hline & 0.0279 \\
\hline USA & $(0.0232)$ \\
\hline & $-0.0637^{* * *}$ \\
\hline China & $(0.0137)$ \\
\hline & 0.0261 \\
\hline Constant & $(0.0162)$ \\
\hline & $0.299^{* * *}$ \\
\hline & $(0.0144)$ \\
\hline Observations & \\
\hline R-squared & 190 \\
\hline & 0.251 \\
\hline
\end{tabular}

Note. Robust standard errors in parentheses.

${ }^{* * *} p<0.01,{ }^{* *} p<0.05,{ }^{*} p<0.1$. 


\title{
Причины исполнения обязательств «Группы двадцати»: институционализация, доминирование, принцип взаимности или клубный принцип ${ }^{1}$
}

\author{
Дж. Киртон, А. Николаева
}

Киртон Джон - профессор, директор Исследовательского центра «Группы двадцати» Университета Торонто; Canada, Toronto ON M5S 3K7, 1 Devonshire Place, Room 308N; E-mail: john.kirton@utoronto.ca

Николаева Алиса - н.с. Исследовательского центра «Группы двадцати» Университета Торонто; Саnada, Toronto ON M5S 3K7, 1 Devonshire Place, Room 308N; E-mail: alisanik@bu.edu

В последние годы развитие многостороннего подхода сталкивается с существенными сложностями. Подъем популистских настроений в западных странах, торговые войны, а также замедление экономического роста подорвали доверие к многосторонним институтам, включая институты многосторонних саммитов. «Группа двадиати» часто критикуется за неэффективное решение проблем и низкий уровень исполнения принимаемых на саммитах обязательств. Тем не менее результаты исследований Исследовательского центра «Группы двадиати» свидетельствуют о том, что члены «двадиатки» все же в той или иной мере выполняют обязательства в период между саммитами. По одним саммитам и темам наблюдается более высокий уровень исполнения, чем по другим. Понимание того, что лежит в основе исполнения обязательств, и как его можно улучшить, имеет важнейшее значение для повышения эффективности работы «Группы двадиати», а также повышения доверия к этой неформальной организации, и даже может повлиять на ее будущее. Данное исследование содержит экспериментальный количественный анализ результатов саммитов «Группы двадиати». Он базируется на стандартной концептуальной модели, способной представить логически обоснованные выводы. Исполнение обязательств перекликается и, следовательно, может быть улучшено через принятие более существенного числа обязательств, проведение министерских встреч и использование специфических катализаторов в формулировках обязательств, при условии взаимодействия членов «Группы двадиати» в сфере исполнения, а не доминирования одного из членов, который задает общий темп, например, США или Китая.

Ключевые слова: «Группа двадцати»; глобальное управление; исполнение обязательств; подотчетность

Для цитирования: Киртон Дж., Николаева А. (2019) Причины исполнения обязательств «Группы двадцати»: институционализация, доминирование, принцип взаимности или клубный принцип // Вестник международных организаций. Т. 14. № 2. С. 80-108 (на русском и английском языках). DOI: 10.17323/1996-7845-201902-04.

\section{Источники}

Cicci A. (2018) G20 Performance on Financial Stability. G20 Argentina: The Buenos Aires Summit / J. Kirton, M. Koch (eds). L.: GT Media Group Ltd. P. 102-04.

Cormier B. (2018) Explaining G8 Compliance: Reciprocity, Ministerial Institutionalization and Accountability. Accountability and Effectiveness in Global Governance / J. Kirton, M. Larionova (eds). Abdingdon: Routledge. P. 183-94.

Freedom House (2018) Freedom in the World 2018: Democracy in Crisis. Режим доступа: https:// freedomhouse.org/report/freedom-world/freedom-world-2018 (дата обращения: 12.11.2018).

von Furstenberg G., Daniels J. (1992) Can You Trust G-7 Promises? // International Economic Insights. Vol. 3. P. 24-27.

\footnotetext{
${ }^{1}$ Статья поступила в редакцию в феврале 2019 г.
} 
Hallink C. (2018) G20 Performance on Development. G20 Argentina: The Buenos Aires Summit / J. Kirton, M. Koch (eds). L.: GT Media Group Ltd. P. 164-65.

Hilbrich S., Schwab J. (2018) Towards a More Accountable G20? Accountability Mechanisms of the G20 and the New Challenges Posed to Them by the 2030 Agenda // International Organizations Research Journal. Vol. 13. No. 4. P. 7-38.

Ikenberry J. (1993) Salvaging the G7 // Foreign Affairs. Vol. 72. P. 132-39.

Ikenberry J. (2001) After Victory: Institutions, Strategic Restraint, and the Rebuilding of Order after Major Wars. Princeton: Princeton University Press.

Keohane R.O. (1984) After Hegemony: Cooperation and Discord in the World Political Economy. Princeton: Princeton University Press.

Keohane R.O. (2006) Accountability in World Politics // Scandinavian Political Studies. Vol. 29. No. 2. P. 75-87.

Keohane R.O. (2011) Global Governance and Legitimacy // Review of International Political Economy. Vol. 18. No. 1. P. 99-109.

Kirton J. (1989) Contemporary Concert Diplomacy: The Seven-Power Summit and the Management of International Order. Paper presented at the Annual Convention of the International Studies Association. London. 29 March - 1 April. Режим доступа: www.g8.utoronto.ca/scholar/kirton198901 (дата обращения: 12.11. 2018).

Kirton J. (2006) Explaining Compliance with G8 Finance Commitments: Agency, Institutionalization and Structure // Open Economies Review. Vol. 17. P. 459-75.

Kirton J., Kokotsis E. (2007) Keeping Faith with Africa's Health: Catalysing G8 Compliance. Governing Global Health: Challenge, Response, Innovation / A. Cooper, J. Kirton, T. Schrecker (eds). Aldershot: Ashgate. P. $157-80$.

Kirton J., Larionova M. (eds) (2018a) Accountability for Effectiveness in Global Governance. Abingdon: Routledge.

Kirton J., Larionova M. (2018b) Accountability for Effectiveness in Global Governance. Accountability and Effectiveness in Global Governance / J. Kirton, M. Larionova (eds). Abingdon: Routledge. P. 3-22.

Kirton J., Roudev N., Sunderland L. (2007) Making Major Powers Deliver: Explaining Compliance with G8 Health Commitments, 1996-2006 // Bulletin of the World Health Organization. Vol. 85. No. 3. P. 192-99.

Kokotsis E. (1999) Keeping International Commitments: Compliance, Credibility, and the G7, 1988-1995. N.Y.: Garland. P. 3-36, 267-89.

Kokotsis E. (2018) G20 Performance on Climate and Energy. G20 Argentina: The Buenos Aires Summit / J. Kirton, M. Koch (eds). L.: GT Media Group Ltd. P. 154-55.

Kulik J. (2018) G20 Performance on Gender Equality. G20 Argentina: The Buenos Aires Summit / J. Kirton, M. Koch (eds). L.: GT Media Group Ltd. P. 130-31.

Larionova M., Rakhmangulov M., Shelepov A. (2018) Explaining G20 and BRICS Compliance. Accountability for Effectiveness in Global Governance / J. Kirton, M. Larionova (eds). L.: Routledge. P. 195-215.

Li Q. (2001) Commitment Compliance in G7 Summit Macroeconomic Policy Coordination // Political Research Quarterly. Vol. 54. P. 355-78.

Marchyshyn M. (2018) G20 Performance on Trade. G20 Argentina: The Buenos Aires Summit / J. Kirton, M. Koch (eds). L.: GT Media Group Ltd. P. 120-21.

Motala M. (2018) G20 Performance on International Taxation. G20 Argentina: The Buenos Aires Summit / J. Kirton, M. Koch (eds). L.: GT Media Group Ltd. P. 114-15.

Putnam R. (1988) Diplomacy and Domestic Politics: The Logic of Two-Level Games // International Organization. Vol. 42. No. 3. P. 427-60.

Rudich D. (2018) G20 Performance on Countering Corruption. G20 Argentina: The Buenos Aires Summit / J. Kirton, M. Koch (eds). L.: GT Media Group Ltd. P. 178-79.

Tops J. (2018) G20 Performance on Infrastructure Development. G20 Argentina: The Buenos Aires Summit / J. Kirton, M. Koch (eds). L.: GT Media Group Ltd. P. 46-47. 
Wang A. (2018) G20 Performance on Economic Governance. G20 Argentina: The Buenos Aires Summit / J. Kirton, M. Koch (eds). L.: GT Media Group Ltd. P. 92-93.

Warren B. (2018a) G20 Performance on Climate Change. G20 Argentina: The Buenos Aires Summit / J. Kirton, M. Koch (eds). L.: GT Media Group Ltd. P. 138-39.

Warren B. (2018b) G20 Performance on Food and Agriculture. G20 Argentina: The Buenos Aires Summit / J. Kirton, M. Koch (eds). L.: GT Media Group Ltd. P. 80-81.

Wendt A. (1999) Social Theory of International Politics. Cambridge: Cambridge University Press.

Williams M. (2018) G20 Performance on Labour and Employment. G20 Argentina: The Buenos Aires Summit / J. Kirton, M. Koch (eds). L.: GT Media Group Ltd. P. 58-59.

World Bank (2018) GDP Growth (Annual \%). World Development Indicators Database. Режим доступа: https://data.worldbank.org/indicator/NY.GDP.MKTP.KD.ZG?view=chart (дата обращения: 12.11.2018). 